\title{
Potential Metabolic Biomarkers in Adult Asthmatics
}

\author{
Soyoon Sim, Youngwoo Choi and Hae-Sim Park *
}

Department of Allergy and Clinical Immunology, Ajou University School of Medicine, 164, Worldcup-ro, Yeongtong-gu, Suwon 16499, Korea; simm27@ajou.ac.kr (S.S.); cyw3789@aumc.kr (Y.C.)

* Correspondence: hspark@ajou.ac.kr; Tel.: +82-31-219-5196; Fax: +82-31-219-5154

Citation: Sim, S.; Choi, Y.; Park, H.-S Potential Metabolic Biomarkers in Adult Asthmatics. Metabolites 2021, 11, 430. https://doi.org/10.3390/ metabo11070430

Academic Editors: María

M. Escribese, André Moreira,

Ibon Eguiluz-Gracia, Craig Wheelock and Alma Villaseñor

Received: 25 May 2021

Accepted: 25 June 2021

Published: 30 June 2021

Publisher's Note: MDPI stays neutral with regard to jurisdictional claims in published maps and institutional affiliations.

Copyright: (c) 2021 by the authors. Licensee MDPI, Basel, Switzerland. This article is an open access article distributed under the terms and conditions of the Creative Commons Attribution (CC BY) license (https:// creativecommons.org/licenses/by/ $4.0 /)$.

\begin{abstract}
Asthma is the most common chronic airway inflammation, with multiple phenotypes caused by complicated interactions of genetic, epigenetic, and environmental factors. To date, various determinants have been suggested for asthma pathogenesis by a new technology termed omics, including genomics, transcriptomics, proteomics, and metabolomics. In particular, the systematic analysis of all metabolites in a biological system, such as carbohydrates, amino acids, and lipids, has helped identify a novel pathway related to complex diseases. These metabolites are involved in the regulation of hypermethylation, response to hypoxia, and immune reactions in the pathogenesis of asthma. Among them, lipid metabolism has been suggested to be related to lung dysfunction in mildto-moderate asthma. Sphingolipid metabolites are an important mediator contributing to airway inflammation in obese asthma and aspirin-exacerbated respiratory disease. Although how these molecular variants impact the disease has not been completely determined, identification of new causative factors may possibly lead to more-personalized and precise pathway-specific approaches for better diagnosis and treatment of asthma. In this review, perspectives of metabolites related to asthma and clinical implications have been highlighted according to various phenotypes.
\end{abstract}

Keywords: asthma; biomarker; diagnosis; inflammation; lipid; metabolite; treatment

\section{Introduction}

Asthma is characterized by chronic airway inflammation with complex interactions among genetic, epigenetic, and environmental factors [1,2], resulting in constant attempts to understand asthma pathogenesis underlying each phenotype. Although the classification of asthma phenotypes as eosinophilic, non-eosinophilic, or paucigranulocytic phenotypes has enabled intensive treatment and improved clinical outcomes [3], attempts to develop novel approaches are needed to unveil the pathogenic mechanisms of asthma. Since the emergence of new technologies, "omics," their application in medical research has been rapidly growing [4]. In particular, metabolomics is one of the latest approaches to detect metabolites for phenotype categorization and biomarker discovery in diverse diseases [5]. Metabolites are the intermediate or end products of cellular metabolism required for the maintenance of biological homeostasis and normal cell function [6]. Therefore, alteration in metabolites reflects physiological or pathological states [7]. With the integration of multiple omics, metabolomics is becoming a more powerful tool in clinical application for early diagnosis, prognosis, and treatment of diseases [8]. Despite an increase in metabolomic studies on asthma, it is not clear how metabolites act as key determinants for each phenotype [9]. This review highlights recent progress in the genomic, transcriptomic, proteomic, and metabolomic signatures involved in the pathogenesis of asthma, suggesting the potential for applying this approach in precision medicine.

\section{Risk Factors in Asthma Pathogenesis}

\subsection{Genetic and Epigenetic Factors}

Asthma pathogenesis is still poorly understood, as the airways are influenced by multiple environmental and genetic factors. Accumulating evidence has supported the 
genetic traits of asthma $[10,11]$, suggesting specific genes involved in some phenotypes of asthma. The conventional studies on asthma-related genes were performed with linkage analysis and positional cloning. More recently, since the first introduction of genomic-wide association studies (GWAS) in asthma [12], multiple genetic variants were validated to explore disease-related regions showing differences in DNA sequences between normal and asthma groups [13]. These findings brought a huge improvement to asthma genetics by identifying novel genetic factors for asthma. However, the gene-gene interaction still remains a problem to solve in genomic analysis [14]. In addition, epigenetic studies have been highlighted focusing on genomic adaption to environmental stimuli, such as DNA methylation, histone modification, or non-coding RNAs, which are not caused by alterations in DNA sequences [15]. With the application of epigenome-wide association studies (EWAS) in asthma, DNA methylation has been suggested to mediate gene expression in immune cells, including $\mathrm{T}$ cell polarization [16] or monocyte differentiation [17]. In particular, methylation of cytosine at the carbon-5 position in CpG dinucleotides is regarded as a key factor for initiating a transcription and regulating cell-specific genes in inflammatory diseases [18].

\subsection{Environmental Factors}

Environmental exposure could impact a rapid increase in the prevalence of asthma in populations with a similar genetic background where allergen exposure is a crucial risk factor for asthma [19]. Sensitization to allergens, such as dust mites and animal dander, is related to Th2 immune response with IgE production and eosinophilia, contributing to the development and exacerbation of allergic asthma [20,21]. Other environmental factors, including smoking, air or occupational pollutants, and virus or bacterial infection, are involved in innate immunity and trigger asthma exacerbation [22]. Air pollutants, including particulate matter, nitrogen dioxide, and sulfur dioxide, are known to aggravate inflammatory response related to oxidative stress and injury in the airways, driving enhanced risk of sensitization to inhaled allergens and symptom exacerbation [23,24].

\section{Identification of "Omics" Markers in Asthma}

\subsection{Genomics}

Numerous genetic studies have revealed that multiple genes are involved in the development and progress of asthma by linkage analysis and association studies. In particular, linkage analysis with positional cloning identified diverse genetic markers related to asthma in chromosomal loci [25-32]. In addition, candidate genes association studies identified asthma-related traits, focusing on different allele frequencies of a single nucleotide polymorphism in case-control studies [33]. Since the application of GWAS to asthma, large meta-analyses in European [34] and American cohorts [35] have identified variable genetic determinants (Table 1). Nevertheless, GWAS have the limitations of a small sample population and lack of significant associations [36]. Moreover, the susceptibility of genetic variants for asthma was not replicated across all relevant studies [34].

Table 1. Summary of genomic analysis in adult asthmatics.

\begin{tabular}{ccc}
\hline \multicolumn{3}{c}{ Linkage Studies with Positional Cloning } \\
\hline ADAM33 & $20 \mathrm{p} 13$ & {$[25]$} \\
\hline DPP10 & $2 \mathrm{q} 14$ & {$[26]$} \\
\hline PHF11 & $13 \mathrm{q} 14$ & {$[27]$} \\
\hline GPRA & $7 \mathrm{p} 14$ & {$[28]$} \\
\hline HLA-G & $6 \mathrm{p} 21$ & {$[29]$} \\
\hline CYFIP2 & $5 \mathrm{q} 33$ & {$[30]$} \\
\hline IRAK3 & $12 \mathrm{q} 14$ & {$[31]$} \\
\hline
\end{tabular}


Table 1. Cont.

\begin{tabular}{|c|c|c|c|}
\hline \multicolumn{4}{|c|}{ Linkage Studies with Positional Cloning } \\
\hline \multirow[t]{2}{*}{ OPN3 } & \multicolumn{2}{|c|}{$1 \mathrm{q}$} & [32] \\
\hline & \multicolumn{2}{|c|}{ Candidate gene association studies } & \\
\hline \multirow{39}{*}{ Asthma } & IL10 & $1 q 31$ & [37] \\
\hline & IL1RN & $2 \mathrm{q} 14$ & [38] \\
\hline & IL1B & $2 q 14$ & [39] \\
\hline & HNMT & $2 q 22$ & [40] \\
\hline & CTLA4 & $2 q 33$ & [41] \\
\hline & CCR3 & $3 p 21$ & [42] \\
\hline & CCR5 & 3 p21 & {$[43,44]$} \\
\hline & TLR9 & $3 p 21.3$ & [45] \\
\hline & MUC7 & $4 q 13-21$ & [46] \\
\hline & PGDS & $4 q 21-22$ & [47] \\
\hline & CSF2 & $5 q 31$ & [37] \\
\hline & IL4 & $5 q 31$ & {$[48,49]$} \\
\hline & IL13 & $5 q 31$ & [50-52] \\
\hline & UGRP1 & $5 q 31-34$ & [53] \\
\hline & ADRB2 & $5 q 32-34$ & {$[54,55]$} \\
\hline & LTC4S & $5 q 35$ & {$[56,57]$} \\
\hline & HLA-DRB1 & 6 p21 & [58-61] \\
\hline & HLA-DPB1 & $6 \mathrm{p} 21$ & [62] \\
\hline & TNF & $6 \mathrm{p} 21$ & {$[58,63-66]$} \\
\hline & LTA & 6 p21 & {$[58,65]$} \\
\hline & TAP1 & $6 \mathrm{p} 21$ & {$[67,68]$} \\
\hline & PAFAH & $6 \mathrm{p} 21$ & [69-71] \\
\hline & EDN1 & 6 p21 & [72] \\
\hline & EOTAXIN2 & 7q11 & [73] \\
\hline & CFTR & $7 q 31$ & [74-77] \\
\hline & NOS3 & $7 q 36$ & {$[37,78]$} \\
\hline & $\mathrm{C} 5$ & $9 q 34$ & [37] \\
\hline & SDF1 & $10 q 11$ & [37] \\
\hline & CC16/CC10 & $11 q 12-13$ & [79-81] \\
\hline & FCER1B & 11q12-13 & [82-88] \\
\hline & GSTP1 & $11 \mathrm{q} 13$ & [89] \\
\hline & AICDA & $12 \mathrm{p} 13$ & {$[90]$} \\
\hline & STAT6 & $12 q 13$ & [91] \\
\hline & NOS1 & $12 q 24$ & {$[92,93]$} \\
\hline & $\mathrm{ACT}$ & $14 q 32$ & [94] \\
\hline & IL4RA & $16 \mathrm{p} 12$ & [95-99] \\
\hline & RANTES & $17 q 11-12$ & {$[100,101]$} \\
\hline & $\mathrm{ACE}$ & $17 q 23$ & {$[102,103]$} \\
\hline & TBXA2R & 19 p13 & [104] \\
\hline
\end{tabular}


Table 1. Cont.

\begin{tabular}{|c|c|c|c|}
\hline \multicolumn{4}{|c|}{ Candidate gene association studies } \\
\hline \multirow{6}{*}{ Asthma severity } & CTLA4 & $2 q 33$ & [105] \\
\hline & IL4 & $5 q 31$ & [106] \\
\hline & ADRB2 & $5 q 32-34$ & [107] \\
\hline & PAFAH & $6 \mathrm{p} 21$ & [69] \\
\hline & IL4RA & $16 \mathrm{p} 12$ & [97] \\
\hline & TGFB1 & $19 q 13$ & [108] \\
\hline \multirow{4}{*}{ Eosinophil counts } & IL10 & $1 \mathrm{q} 31$ & [72] \\
\hline & STAT6 & $12 q 13$ & [109] \\
\hline & NOS1 & $12 q 24$ & {$[72]$} \\
\hline & EOTAXIN1 & $17 q 21$ & [110] \\
\hline \multirow{14}{*}{$\begin{array}{l}\text { Total IgE in general } \\
\text { population }\end{array}$} & CTLA4 & $2 q 33$ & [41] \\
\hline & IL4 & $5 q 31$ & [111] \\
\hline & CD14 & $5 q 31$ & {$[112,113]$} \\
\hline & HLA-DRB1 & $6 \mathrm{p} 21$ & [114-116] \\
\hline & PAFAH & $6 \mathrm{p} 21$ & [70] \\
\hline & IFNGR1 & $6 q 23$ & [117] \\
\hline & FCER1B & $11 \mathrm{q} 13$ & [84] \\
\hline & AICDA & 12 p13 & [90] \\
\hline & IFNG & $12 q 21$ & [118] \\
\hline & NOS1 & $12 q 24$ & [72] \\
\hline & IL4RA & $16 \mathrm{p} 12$ & {$[95,99,119,120]$} \\
\hline & TGFB1 & $19 q 13$ & [121] \\
\hline & IFNGR2 & $21 q 22$ & [117] \\
\hline & IL13RA1 & $\mathrm{Xq13}$ & [51] \\
\hline \multirow{6}{*}{$\begin{array}{l}\text { Total IgE in } \\
\text { asthmatics }\end{array}$} & IL10 & $1 \mathrm{q} 31$ & {$[121,122]$} \\
\hline & CTLA4 & $2 q 33$ & [123] \\
\hline & IL4 & $5 q 31$ & [124] \\
\hline & NOS3 & $7 q 36$ & [125] \\
\hline & FCER1B & $11 q 13$ & {$[87]$} \\
\hline & EOTAXIN1 & $17 q 21$ & [73] \\
\hline \multirow{5}{*}{ Specific IgE } & IL4 & $5 q 31$ & {$[126]$} \\
\hline & HLA-DPB1 & $6 \mathrm{p} 21$ & {$[127,128]$} \\
\hline & PAFAH & $6 \mathrm{p} 21$ & {$[70]$} \\
\hline & NOS3 & $7 q 36$ & [125] \\
\hline & FCER1B & 11q13 & [129] \\
\hline
\end{tabular}


Table 1. Cont.

\begin{tabular}{|c|c|c|c|}
\hline \multicolumn{4}{|c|}{ Candidate gene association studies } \\
\hline \multirow{13}{*}{ AHR/BHR } & IL10 & $1 \mathrm{q} 31$ & [37] \\
\hline & CTLA4 & $2 q 33$ & {$[41,105]$} \\
\hline & CSF2 & $5 q 31$ & [37] \\
\hline & IL13 & $5 q 31$ & [50] \\
\hline & ADRB2 & $5 q 32-34$ & {$[130,131]$} \\
\hline & LTC4S & $5 q 35$ & [37] \\
\hline & TNF & $6 \mathrm{p} 21$ & {$[37,132,133]$} \\
\hline & LTA & 6 p21 & [132] \\
\hline & NOS3 & $7 q 36$ & {$[37]$} \\
\hline & FCER1B & $11 q 13$ & [129] \\
\hline & ACT & $14 q 32$ & [94] \\
\hline & IL4RA & $16 \mathrm{p} 12$ & [95] \\
\hline & NOS2A & 17cen-q11 & {$[37]$} \\
\hline & IL4 & $5 q 31$ & [134] \\
\hline & ADRB2 & $5 q 32-34$ & [135] \\
\hline FEV1/FVC & LTC4S & $5 q 35$ & [136] \\
\hline & IL4RA & $16 \mathrm{p} 12$ & [106] \\
\hline & EOTAXIN1 & $17 q 21$ & [110] \\
\hline \multicolumn{4}{|c|}{ Genome-wide association studies } \\
\hline CRCT1 & & & [137] \\
\hline IL6R & & & {$[137,138]$} \\
\hline PYHIN1 & & & {$[35,137]$} \\
\hline DENND1B/CRB1 & & & [137] \\
\hline IL18R1/IL1RL1/IL1RL2 & & & {$[34,35,137-139]$} \\
\hline DPP10 & & & [140] \\
\hline D2HGDH & & & [137] \\
\hline USP38/GAB1 & & & {$[137,141]$} \\
\hline PDE4D & & & [142] \\
\hline TSLP/SLC22A5 & & & {$[34,137,139,141,143]$} \\
\hline RAD50/NDFIP1 & & & {$[137,144]$} \\
\hline ADRA1B & & & [140] \\
\hline IL13 & & & {$[34,144]$} \\
\hline HLA-DP/DQ/DR & & & {$[34,137,143-146]$} \\
\hline BTNL2 & & & [137] \\
\hline CDHR3 & & & [137] \\
\hline TEK & & & [143] \\
\hline IL-33 & & & {$[34,138]$} \\
\hline PTGES & & & [143] \\
\hline
\end{tabular}


Table 1. Cont.

\begin{tabular}{ccc}
\hline & Genome-wide association studies & \\
\hline GATA3 & $10 \mathrm{p} 14$ & {$[141]$} \\
\hline JMJDIC/REEP3 & $10 \mathrm{q} 21$ & {$[143]$} \\
\hline CDK2/IKZF4 & $12 \mathrm{q} 13$ & {$[137]$} \\
\hline RORA & $15 q 22$ & {$[34,35,137]$} \\
\hline SMAD3 & $15 q 22$ & {$[34,137]$} \\
\hline ORMDL3/GSMDB/IKZF3 & $17 q 21$ & {$[34,35,137-139]$} \\
\hline PRNP & 20 pter-p12 & {$[140]$} \\
\hline IL2RB & $22 q 12.3$ & {$[34,35,137,138]$} \\
\hline
\end{tabular}

ADAM33, a disintegrin and metalloproteinase 33; DPP10, dipeptidyl peptidase 10; PHF11, PHD finger protein 11; GPRA, G-protein-coupled receptor for asthma susceptibility; HLA-G, human leukocyte antigen-G; CYFIP2, cytoplasmic FMR1-interacting protein 2; IRAK3, IL-1 receptor-associated kinase 3; OPN3, opsin 3; AHR, airway hyperresponsiveness; BHR, bronchial hyperresponsiveness; FEV1, forced expiratory volume; FVC, forced vital capacity; IL, interleukin; HNMT, histamine N-methyltransferase; CTLA4, cytotoxic T lymphocyte antigen 4; CCR, CC chemokine receptor; TLR, toll-like receptor; MUC, mucin; PGDS, prostaglandin D synthase; CSF2, colony stimulating factor 2; UGRP1, uterus globulin associated protein 1; ADRB2, adrenoceptor beta 2; LTC4S, leukotriene $\mathrm{C} 4$ synthase; TNF, tumor necrosis factor; LTA, lymphotoxin alpha; TAP1, antigen peptide transporter 1; PAFAH, platelet activating factor acetylhydrolase; EDN1, endothelin 1; CFTR, cystic fibrosis transmembrane conductance regulator; NOS, nitric oxide synthase; SDF1, stromal cell-derived factor 1; CC, clara cell secretory protein; FCER1B, high affinity immunoglobulin epsilon receptor subunit beta; GSTP1, glutathione S-transferase Pi 1; AICDA, activation induced cytidine deaminase; STAT6, signal transducer and activator of transcription 6 ; ACT, alpha-1-antichymotrypsin; IL4RA, interleukin 4 receptor alpha; RANTES, regulated on activation, normal T cell expressed and secreted; ACE, angiotensin converting enzyme; TBXA2R, thromboxane A2 receptor; TGFB1, transforming growth factor beta 1; IFNGR, interferon gamma receptor 1; IFNG, interferon gamma; IL13RA1, interleukin 13 receptor alpha 1; CRCT1; cysteine-rich C-terminal 1; IL6R, interleukin 6 receptor; PYHIN1, pyrin, and HIN domain family member 1; D2NND1B, DENN domain containing 1B; CRB1, crumbs cell polarity complex component 1; IL18R1, interleukin 18 receptor 1; IL1RL, interleukin 1 receptor like; D2HGDH, D-2hydroxyglutarate dehydrogenase; USP38, ubiquitin specific peptidase 38; GAB1, growth factor receptor bound protein 2-associated binding protein 1; PDE4D, phosphodiesterase 4D; TSLP, thymic stromal lymphopoietin; SLC22A5, solute carrier family 22 member 5; RAD50, RAD50 double strand break repair protein; NDFIP1, Nedd4 family interacting protein 1; ADRA1B, adrenoceptor alpha 1B; HLA, major histocompatibility complex; BTNL2, butyrophilin like 2; CDHR3, cadherin related family member 3; TEK, TEK receptor tyrosine kinase; PTGES, prostaglandin E synthase; GATA3, GATA binding protein 3; JMJD1C, jumonji domain containing 1C; REEP3, receptor accessory protein 3; CDK2, cyclin dependent kinase 2; IKZF, IKAROS family zinc finger; RORA, RAR related orphan receptor A; SMAD3, mothers against decapentaplegic homolog 3; ORMDL3, ORMDL sphingolipid biosynthesis regulator 3; GSMDB, gasdermin B; PRNP, prion protein; IL2RB, interleukin 2 receptor subunit beta.

\subsection{Transcriptomics}

Transcriptomics quantifies transcripts in organisms to identify differentially expressed genes under specific conditions. The main analyzing tools for transcriptomics include microarrays and RNA sequencing [147]. Transcriptomics is usually carried out in blood because of its great efficiency and convenience for analyzing gene expression [148]. Some studies have performed transcriptomic analysis in blood [149,150], bronchial tissue [151-154], sputum [155-159], nasal brushings [160], bronchoalveolar lavage fluid (BALF) [161], and mixed samples [162], facilitating differential phenotypes in asthma. Finally, recent studies found 90 novel genetic classifiers for asthma, which could be utilized as potential biomarkers [160]. In addition, several studies have investigated distinct gene profiles to determine the severity of asthma (Table 2). 
Table 2. Summary of transcriptomic analyses in adult asthmatics.

\begin{tabular}{lllll}
\hline Population & Methods & Purpose & Findings \\
\hline Blood & & & Ref
\end{tabular}

\begin{tabular}{lll}
\hline $\begin{array}{l}\text { Exacerbation sample in } \\
\text { adult asthmatics }\end{array}$ & $\begin{array}{l}\text { Microarray and } \\
\text { qPCR with pathway } \\
(n=118)\end{array}$ & $\begin{array}{l}\text { To identify the } \\
\text { exacerbation-associated gene } \\
\text { analysis }\end{array}$
\end{tabular}

TLR activation pathway with elevations in type 1 interferon and

IL-15 genes is associated with asthma exacerbation.

\section{Nonsmoking}

SA/smoking

SA/nonsmoking mild

to moderate

asthma/nonsmoking

controls

$(n=246 / 88 / 77 / 87)$
To find the transcriptional differences between subgroups of asthmatics and non-asthmatics in whole blood
Differentially expressed genes in immune cells of severe asthmatics. Gene sets related to chemotaxis, mobilization, migration, and infiltration of myeloid cells contribute to asthma severity.
Airway epithelial cell

nonsmoking
Microarra asthma/nonsmoking $\mathrm{HCs} /$ smoking controls $(n=42 / 28 / 16)$
To explore the distinct gene expression related to airway dysfunction and corticosteroid treatment in epithelial cells of asthmatics
Identification of 22 differentially expressed genes in asthmatics. IL-13-derived asthma-associated genes (CLCA1, periostin, and serpinB2) are decreased by corticosteroid treatment with an improvement in lung function.

Phenotyping of asthma as Th2-high and Th2-low based on CLCA1, periostin, and sepinB2 gene expression.

To define the molecular Asthmatics/HCs $(n=42 / 28)$

Microarray and qPCR phenotypes based on type 2 cytokines-induced gene expression in epithelial brushings of asthmatics

Th2-high asthma has worse clinical outcomes (lower lung function, higher serum IgE, and blood/airway eosinophilia) and inflammatory features (subepithelial fibrosis and increase of mucin stores).
To investigate the pathogenesis of severe asthma and the influences of blood, sputum, and submucosal eosinophils or neutrophils on the gene expression in bronchial brushing

SA/moderate asthma with ICS/mild asthma with

ICS/mild-to-moderate asthma with no ICS/HCs

$(n=51 / 19 / 22 / 37 / 26)$
Microarray with WGCNA, LIMMA, and pathway analysis
To identify specific genetic networks to be associated with asthma severity
7 genes (COX-2, ADAM-7

SLCO1A2, TMEFF2, TRPM-1, and 2 unnamed genes) are positively correlated with blood and submucosal eosinophilia with thick lamina reticularis and elevated $\mathrm{F}_{\mathrm{E}} \mathrm{NO}$.
Asthma severity has a positive correlation with a network related to mitosis/cell division and T2 inflammation, but a negative correlation with a network related to epithelial growth/repair, cell integrity/remodeling, and neuronal function/development.

Sputum

Asthmatics/HCs $(n=59 / 13)$
Microarray and qPCR with GO and pathway analysis
To establish 3 distinct transcriptional asthma phenotypes (TAPs) considering clinical status and gene expression in the sputum of asthmatics
Classification of asthma phenotypes as eosinophilic, neutrophilic, or paucigranulocytic asthma based on the predominance of immune cells in sputum. are involved in the pathogenesis of neutrophilic asthma. 
Table 2. Cont.

\begin{tabular}{|c|c|c|}
\hline Population & Methods & Purpose \\
\hline $\begin{array}{l}\text { Asthmatics/HCs } \\
(n=37 / 15)\end{array}$ & qPCR & $\begin{array}{l}\text { To determine genetic } \\
\text { profiling related to Th2 } \\
\text { cytokines in the sputum cells } \\
\text { of asthmatics for the } \\
\text { categorization of asthma } \\
\text { phenotypes }\end{array}$ \\
\hline
\end{tabular}

Standardization of IL-4, IL-5, and

IL-13 gene expression for

classification as Th2-high and

Th2-low subtypes (Th2 gene mean).

Th2-high asthma has poor clinical

phenotypes

outcomes (low lung function and

blood eosinophilia) with elevation in

mast cell/eosinophil-related genes.

Ref.

Identification of 23 differentially

expressed genes across eosinophilic, neutrophilic, and paucigranulocytic

To validate genetic

Asthmatics/HCs

$(n=106 / 20)$

Microarray and qPCR

biomarkers for inflammatory

phenotypes of asthma and

prediction of ICS treatment

response phenotypes.

The 3 genes for eosinophilic asthma

(CLC, CPA3, and DNASE1L3) and 3

for neutrophilic asthma (IL1B, ALPL,

and CXCR2) are validated with

distinct alterations after ICS

treatments.

High T2-network gene expression in the T2-high asthma comes from the interaction of various immune cells (eosinophils, mast cells, basophils, and dendritic cells), leading to severe airway dysfunction.

RNA seq with WGCNA and pathway analysis
To identify genetic networks in sputum immune cells of asthmatics for clustering them into T2-high and T2-low subgroups
CD8+T cell network gene expression is lower in T2-low asthma and negatively correlated with body mass index.

Identification of 2 molecular clusters in elderly asthmatics with increased OXPHOS and EMT gene sets, respectively.

The OXPHOS/UPR system related to oxidative stress leads to inflammatory response and immune function dysregulation in the airways of elderly asthmatics. The EMT gene sets contribute to airway remodeling with lower lung function in elderly asthmatics.

\begin{tabular}{|c|c|c|c|c|}
\hline \multicolumn{5}{|l|}{ Nasal brushings } \\
\hline $\begin{array}{l}\text { Mild-to-moderate } \\
\text { asthmatics/HCs } \\
(n=66 / 124)\end{array}$ & $\begin{array}{l}\text { Microarray and RNA } \\
\text { seq with pathway and } \\
\text { classification analysis }\end{array}$ & $\begin{array}{l}\text { To validate nasal } \\
\text { brush-based classifier genes } \\
\text { for the diagnosis of asthma }\end{array}$ & $\begin{array}{l}\text { Identification of } 90 \text { genes as a nasal } \\
\text { classifier for mild-to-moderate } \\
\text { asthma }\end{array}$ & [160] \\
\hline \multicolumn{5}{|l|}{ BALF } \\
\hline $\begin{array}{l}\text { SA/moderate asthma } \\
\text { with ICS/mild asthma } \\
\text { with } \\
\text { ICS/mild-to-moderate } \\
\text { asthma with no } \\
\text { ICS/HCs } \\
(n=44 / 15 / 18 / 40 / 37)\end{array}$ & $\begin{array}{l}\text { LIMMA, WGCNA, GO } \\
\text { and pathway analysis }\end{array}$ & $\begin{array}{l}\text { To determine severity-related } \\
\text { genes and influence of } \\
\beta \text {-agonist use on gene } \\
\text { expression in BAL immune } \\
\text { cells }\end{array}$ & $\begin{array}{l}\text { Higher BAL neutrophils with } \\
\text { increased gene expression related to } \\
\text { TNF- } \alpha \text { and type } 1 \text { interferon } \\
\text { pathway in SA. } \\
\text { Several severity-related genes are } \\
\text { within or close to asthma } \\
\text { susceptibility loci ( } 5 q, 17 q, 1 p) \text {. } \\
\text { A specific gene network related to } \\
\text { cAMP signaling is associated with } \\
\text { asthma severity and } \beta \text {-agonist } \\
\text { exposure. }\end{array}$ & [161] \\
\hline
\end{tabular}


Table 2. Cont.

\begin{tabular}{ccccc}
\hline Population & Methods & Purpose & Findings & Ref. \\
\hline Mixed & & &
\end{tabular}

Adult/childhoodonset SA $(n=253 / 158)$
To identify gene signatures in adult-onset compared to childhood-onset SA using diverse samples (nasal brushings, bronchial brushings, and sputum)
Identification of 5 differentially expressed gene signatures in nasal brushings, 6 in bronchial brushings, and 3 in sputum.

Specific genes related to immune cells (eosinophils, mast cell, ILC3) and type 2 inflammation are up-regulated in adult-onset SA.

HCs, healthy controls; SA, severe asthma; ICS, inhaled corticosteroid; qPCR; quantitative PCR; WGCNA, weighted gene co-expression network analysis; LIMMA, linear models for microarray data; GO, gene ontology; GSCA, gene set co-expression analysis; PBMC, peripheral blood mononuclear cell; BALF, bronchoalveolar lavage fluid; TLR, toll-like receptor; CLCA1, chloride accessory 1; COX-2, cyclooxygenease-2; ADAM-7, a disintegrin and metalloproteinase domain-containing protein 7; SLCO1A2, solute carrier organic anion transporter family member 1A2; TMEFF2, transmembrane protein with epidermal growth factor like and two follistatin like domains 2 ; TRPM-1, transient receptor potential cation channel subfamily M member 1; CLC. Charcot-leydon crystal protein; CPA3, carboxypeptidase A3; DNASE1L3, deoxyribonuclease 1-like 3; ALPL, alkaline phosphatase, tissue-nonspecific isozyme; CXCR2, chemokine (C-X-C motif) receptor 2; OXPHOS, oxidative phosphorylation; UPR, unfolded protein response; EMT, epithelial-mesenchymal transition; cAMP, cyclic adenosine $3^{\prime}, 5^{\prime}$-monophosphate; ILC3, innate lymphoid cell 3.

\subsection{Proteomics}

Proteomic studies include protein identification, quantification or localization, posttranslational modification, and protein-protein interactions [163]. Liquid chromatography is a typical analyzing tool for proteomics with coupling of mass spectrometry (MS) [164]. Several studies have performed proteomic analysis and identified different protein profiles of asthmatics in serum [165], sputum [166,167], BALF [168-171], or bronchial biopsy [172] (Table 3). Commonly, these proteins have been found to be involved in multiple biological processes, such as immune response, defense response, lipid metabolism, molecular transport, cell adhesion, and complement activation [166,168,172].

Table 3. Summary of proteomic analyses in adult asthmatics.

\begin{tabular}{|c|c|c|c|}
\hline Population & Methods & Purpose & Findings \\
\hline \multicolumn{4}{|l|}{ Serum } \\
\hline $\begin{array}{l}\text { AIA/ATA/HCs } \\
(n=30 / 24 / 21)\end{array}$ & $\begin{array}{l}\text { 2D-PAGE, MALDI-TOF } \\
\text { MS, and ELISA }\end{array}$ & $\begin{array}{l}\text { To investigate } \\
\text { differentially expressed } \\
\text { proteins in AIA }\end{array}$ & $\begin{array}{l}\text { Identification of distinct protein expression i } \\
\text { AIA as complement components, modified } \\
\text { albumin, apolipoprotein, PRO2619, } \\
\text { hypothetical protein, and SPOCD1 protein. } \\
\text { C3a and C4a levels are higher in AIA and } \\
\text { correlated with FEV } \text {, suggesting the }_{\text {pathogenic role of complements in AIA. }}\end{array}$ \\
\hline
\end{tabular}

Sputum

Asthmatics with EIB/those without $\mathrm{EIB} / \mathrm{HCs}$ $(n=5 / 5 / 5)$

LC-MS/MS with GO and network analysis
To determine the contribution of specific proteins to asthma and susceptibility for EIB
10 up-regulated (SERPINA1) and 7 down-regulated proteins (S100A9, S100A8, SMR3B, and SCGB1A1) in asthmatics are related to defense response, inflammation, and [166] protease inhibitory activity. 9 proteins including $\mathrm{C} 3$ and $\mathrm{HPX}$ are susceptible to EIB in asthmatics.

6 increased and 7 decreased proteins in severe uncontrolled asthma with neutrophilic inflammation are related to

$\mathrm{UA} / \mathrm{PC} / \mathrm{CA} / \mathrm{COPD} / \mathrm{HCs}$ $(n=20 / 35 / 21 / 21 / 8)$
2D-PAGE, MALDI-TOF MS, and ELISA
To identify biomarkers for severe UA with neutrophilic inflammation inflammatory/immunity/enzyme activity, cysteine protease inhibitor, signaling, and cytoskeleton functions.

S100A9 is suggested as a UA biomarker contributing to neutrophilic airway inflammation and steroid resistance. 
Table 3. Cont.

\begin{tabular}{|c|c|c|}
\hline Population & Methods & Purpose \\
\hline BALF & & \\
\hline
\end{tabular}

\section{Asthmatics/HCs} $(n=4 / 3)$
SDS-PAGE,

nano-HPLC-MS/MS, and ELISA with GO analysis
To verify protein expression changes before and after segmental allergen challenge in asthmatics

Alterations in protein expression related to diverse biological functions after segmental allergen challenge in asthmatics. Several signature proteins released from immune cells (CLC, MBP, EDN, ECP, CRISP-3, and MMP-9) are elevated after challenge. Differentially expressed proteins are involved in various molecular functions (hydrolase activity, protein binding, and calcium ion binding) and biological process (immune response, lipid metabolism, transport, and signal transduction).

Higher concentrations of IL-4 and gelsolin in BALF of asthmatics.

To demonstrate the 2D-PAGE, MALDI-TOF influences of IL-4 MS, and ELISA with stimulation on gelsolin Atopic asthmatics/HCs functional analysis secretion in BALF of IL-4 treatment induces gelsolin expression in airway epithelial cells of asthmatics for mucus asthmatics viscosity control and innate antimicrobial activity.

\section{To investigate the} oxidative mechanisms in asthmatic airways and allergen-induced mouse models
Lower activity of catalase function in asthmatics contributes to increased oxidative stress, driving chronic and severe airway inflammation.

$\begin{array}{ll}\text { Asthmatics/HCs } & \text { 2D-PAGE, SDS- } \\ (n=11 / 19) & \text { and MS/MS }\end{array}$

\section{Affinity}

chromatography and

ESI LC-MS/MS with

functional analysis
To identify the function of galectins in asthmatic airways
Differential airway localization of galectin-3 in epithelium, endothelium, smooth muscle cells, and fibroblasts, as well as galectin-8 in plasma cells.

Distinct profiles of galectin-bound proteins in asthmatics suggest its linkage with eosinophilic inflammation and airway remodeling.

Bronchial biopsy

\begin{tabular}{|c|c|c|c|}
\hline $\begin{array}{l}\text { Asthmatics/HCs } \\
(n=12 / 3)\end{array}$ & $\begin{array}{l}\text { iTRAQ LC-MS/MS with } \\
\text { functional and pathway } \\
\text { analysis }\end{array}$ & $\begin{array}{l}\text { To determine distinct } \\
\text { proteins and related } \\
\text { biological pathways } \\
\text { related to asthmatics and } \\
\text { their alterations by ICS } \\
\text { treatment. }\end{array}$ & $\begin{array}{l}\text { Identification of } 7 \text { significantly different } \\
\text { proteins between asthmatics and HCs related } \\
\text { to multiple biological functions (hematological } \\
\text { system development/function, lipid } \\
\text { metabolism, molecular transport, signaling, } \\
\text { and tissue development). } \\
\text { ICS treatment alters protein expression related } \\
\text { to immune cell trafficking, tissue development, } \\
\text { and hematological systems } \\
\text { development/function. }\end{array}$ \\
\hline
\end{tabular}

AIA, aspirin-induced asthma; ATA, aspirin-tolerant asthma; HCs, healthy controls; EIB, exercise-induced bronchoconstriction; UA uncontrolled asthma; PC, partially controlled asthma; CA, controlled asthma; COPD, chronic obstructive pulmonary diseases; 2D-PAGE, two-dimensional gel electrophoresis; MALDI, matrix-assisted laser desorption and ionization; TOF, time-of-flight; MS, mass spectrometry; LC, liquid chromatography; HPLC, high-performance liquid chromatography; ESI, electrospray ionization; iTRAQ, isobaric tag for relative and absolute quantitation; SPOCD1, spen paralogue and orthologue C-terminal domain containing 1; SERPINA1, serpin peptidase inhibitor; S100A9, S100 calcium binding protein A9; S100A8, S100 calcium-binding protein A8; SMR3B, submaxillary gland androgen-regulated protein 3B; SCGB1A1, secretoglobin; HPX, hemopexin; CLC, charcot-leyden crystal protein; MBP, major basic protein; EDN, eosinophilderived neurotoxin; ECP, eosinophil cationic protein; CRISP-3, cysteine-rich secretory proteins; MMP-9, matrix metalloproteinase-9.

\subsection{Metabolomics}

Metabolomics is an analysis of low molecular compounds involved in biological processes [6]. For metabolic profiling, MS has been widely employed because of its simplicity and sensitivity [173]. Through its combination with chromatography, MS has become a more powerful tool with high resolution and accuracy, extending its application across biological and medical fields [174]. In addition, nuclear magnetic resonance (NMR) spectroscopy was introduced for an alternative analytic tool, using the differences in the direction and speed of nuclear spin on the magnetic field [175]. Metabolic profiling could be performed in various biospecimens according to its purpose (Table 4). Most studies have used blood [176-184], urine [185-187], or sputum samples [184], since they are easy 
to collect and are reflective of whole body metabolism [188]. A few studies have analyzed exhaled breath condensate [189-193] and BALF because of their relevance to the airway physiology [194].

Table 4. Summary of metabolomic analyses in adult asthmatics.

\begin{tabular}{|c|c|c|}
\hline Population & Methods & Purpose \\
\hline \multicolumn{3}{|l|}{ Blood } \\
\hline $\begin{array}{c}\text { Asthmatics/HCs } \\
(n=147 / 2778)\end{array}$ & ESI-MS/MS & $\begin{array}{l}\text { To investigate lipid } \\
\text { metabolic biomarkers } \\
\text { associated with } \\
\text { asthma candidate } \\
\text { genes by genomic } \\
\text { and metabolomic } \\
\text { analysis in the sera of } \\
\text { asthmatics }\end{array}$ \\
\hline $\begin{array}{l}\text { Asthmatics /HCs } \\
\quad(n=39 / 26)\end{array}$ & ${ }^{1} \mathrm{H}-\mathrm{NMR}$ & $\begin{array}{l}\text { To demonstrate } \\
\text { distinct metabolic } \\
\text { profiling in the sera } \\
\text { of asthmatics and } \\
\text { identify the potential } \\
\text { biomarkers for } \\
\text { asthma }\end{array}$ \\
\hline
\end{tabular}

To explore metabolic changes and related mechanisms in the sera of mild asthmatics for novel prognostic markers
151 different metabolites between asthmatics and HCs.

2 significant metabolites (PC.ae.C42:1 and PC.ae.C42:5) are associated with current asthma. 6 SNPs exert effects on the production of asthma-associated metabolites: 2 SNPs at $17 \mathrm{q} 21$ (PSMD3, MED24) on PC.ae.C42:4, PC.ae.C42:5, PC.ae.C44:5, PC.ae.C44:6, and 1 SNP at TSLP gene on PC.aa.C34:4, SM.C20:2 and IL1RL1 gene on SM.C20:2.

10 significant metabolites in asthmatics: increase of methionine and glutamine and decrease of formate, choline, histidine, acetate, glucose, phosphocholine, arginine, and methanol.

$\mathrm{FEV}_{1}$ has a positive correlation with choline and arginine, but a negative correlation with acetone.

14 significant metabolites in asthmatics and 8 potential clinical indicators for asthma: succinic acid, 3,4-dihydroxybenzoic acid, inosine, 5-aminovaleric acid, phenylalanine, ascorbate, dehydroascorbic acid, and 2-ketovateric acid. hypoxia metabolism, and urea cycle) are associated with asthma.

15 significant metabolites across mild/moderate/severe asthma and HCs. 6 significant metabolites are correlated with ICS doses: DHEA-S, cortisone, ProHyp, pipecolate, To determine distinct N-palmitoyltaurine, and cortisol.

Mild/moderate/severe asthmatics/HCs $(n=12 / 20 / 22 / 22)$

LC-HRMS, MS/MS serum metabolic profiles related to asthma severity and steroid treatment

2 primary metabolic clusters are correlated with asthma severity: decrease of DHEA-S and increase of OEA, S1P, N-palmitoltaurine, 22-hydroxycholesterol, and xanthine. Targeted analysis for lipid metabolites reveals increases in specific ceramides, sphingomyelins, eicosanoids, and fatty acids and their correlation with asthma severity and ICS doses.

To identify differential metabolic patterns and pathways in specific clinical inflammatory phenotypes
18 potential metabolites for diagnostic biomarkers for EA and NEA.

3 significant metabolic pathways related to glycerophospholipid, retinol, and sphingolipid for asthma pathogenesis.
EA/NEA/HCs

$(n=13 / 16 / 15)$

UPLC-MS/MS

To investigate the role of prostaglandin $\mathrm{D}_{2}$
Allergic asthma/HCs $(n=32 / 50)$
GC-NICI-MS and its metabolites in the early asthmatic response to allergens
Targeted analysis in plasma shows early increase in $9 \alpha, 11 \beta$-Prostaglandin $F_{2}$ after allergen challenge induced by mast cell activation. 
Table 4. Cont.

\begin{tabular}{|c|c|c|c|c|}
\hline Population & Methods & Purpose & Findings & Ref. \\
\hline $\begin{array}{l}\text { NSA/SA/HCs } \\
(n=10 / 10 / 10)\end{array}$ & $\begin{array}{c}\text { UHLPC-MS/MS, } \\
\text { GC/MS }\end{array}$ & $\begin{array}{l}\text { To determine the } \\
\text { involvement of } \\
\text { biochemical } \\
\text { metabolism in } \\
\text { asthma and its } \\
\text { severity }\end{array}$ & $\begin{array}{l}25 \text { significant metabolites for asthmatics mostly } \\
\text { related with lipid metabolism, } 16 \text { for severe } \\
\text { asthma with steroid/amino acid metabolism, } \\
\text { and } 13 \text { for high } \mathrm{F}_{\mathrm{E}} \mathrm{NO} \text { with amino } \\
\text { acid/lipid/bile acid metabolism. } \\
\text { Increased taurine, nicotinamide, AMP, and } \\
\text { arachidonate in asthmatics. } \\
\text { Decreased 1-steraroyylglycerol, } \\
\text { degydroisoandrosterone sulfate, and } \\
\text { androsterone sulfate in severe asthma. } \\
\text { Contribution of valine, isoleucine, and } \\
\text { ornithine to high } \mathrm{F}_{\mathrm{E}} \mathrm{NO} \text { in asthmatics. }\end{array}$ & [182] \\
\hline $\begin{array}{l}\text { Asthmatics / HCs } \\
\quad(n=35 / 32)\end{array}$ & UHPLC-MS/MS & $\begin{array}{l}\text { To identify the role of } \\
\text { lipid metabolism for } \\
\text { asthma and IgE levels } \\
\text { by lipidomic analysis } \\
\text { in plasma }\end{array}$ & $\begin{array}{l}10 \text { lipid species for asthma diagnosis: } \mathrm{PE}(38: 1) \text {, } \\
\text { PE(18:1p/22:6), PE(20:0/18:1), SM(d18:1/18:1), } \\
\text { TG(17:0/18:1/18:1), TG(16:0/16:0/18:1), } \\
\text { PI(16:0/20:4), PG(44:9), Cer(d16:0/27:2), and } \\
\text { LPC(22:4). } \\
\text { Correlation of PE(20:0/18:1) and } \\
\text { TG(16:0/16:0/18:1) IgE levels in asthmatics. }\end{array}$ & [183] \\
\hline
\end{tabular}

Asthmatics

$(n=10)$

GC $\times$ GC-TOF-MS H-NMR

To identify the urinary metabolic changes related to asthma exacerbation

Contribution of lipid peroxidation to asthma exacerbation with an increase of alkanes and aldehydes in urine.

Threonine, alanine, carnitine acetylcarnitine, and trimethylamine- $\mathrm{N}$-oxide are increased; acetate, citrate, malonate, Hippurate, dimethylglycine, and phenylacetylglutamine are decreased in exacerbated condition.

To demonstrate the

Asthmatics $(n=57)$ GC $\times$ GC-TOF-MS metabolites related to lipid peroxidation on asthma and its clinical parameters influences of

Increase of urine metabolites related to lipid peroxidation in asthma related to clinical characteristics (asthma severity scores, $\mathrm{FEV}_{1}$, $\mathrm{F}_{\mathrm{E}} \mathrm{NO}$, blood eosinophils, and serum $\mathrm{IgE}$ ).

Higher concentration of urinary metabolites related to $\mathrm{PGD}_{2}, \mathrm{PGF}_{2 \alpha}, \mathrm{PGE}_{2}, \mathrm{TXA}_{2}$,

To investigate urinary isoprostanes, and CysLTs pathway in SA. eicosanoid Lower concentration of 2,3-dinor-TXB 2 and metabolism in asthma for its phenotyping and association with asthma therapeutic agents
8,12 -iso-iPF $2 \alpha-\mathrm{VI}$ in the OCS-treated group and

2,3-dinor-11 $\beta-\mathrm{PGF}_{2 \alpha}, \mathrm{LTE}_{4}$, and

11-dehydro-TXB ${ }_{2}$ in the omalizumab-treated group.

Correlation of urinary $\mathrm{LTE}_{4}$ with T2 inflammation markers in asthma (low lung function, blood/sputum eosinophils, and serum $\operatorname{IgE} /$ periostin/IL-13).

Exhaled breath condensate (EBC)

\section{Asthmatics/HCs}

$(n=82 / 35)$
${ }^{1} \mathrm{H}-\mathrm{NMR}$
To determine EBC metabolomic profiles for phenotype comparisons and ICS use
5 distinct spectral regions for asthmatics (0.16-0.18, 0.78-0.84, 0.88-0.94, 7.36-7.42, and 7.44-7.52 ppm)

2 significant spectra regions for sputum eosinophilia, 7 for sputum neutrophilia, 1 for asthma control, and 8 for steroid use. 
Table 4. Cont.

\begin{tabular}{|c|c|c|c|c|}
\hline Population & Methods & Purpose & Findings & Ref. \\
\hline $\begin{array}{l}\mathrm{SA} / \text { mild-to- } \\
\text { moderate asthma } \\
\quad(n=15 / 21)\end{array}$ & $\begin{array}{c}\text { UHPLC-ESI-MS } \\
{ }^{1} \mathrm{H}-\mathrm{NMR}\end{array}$ & $\begin{array}{l}\text { To validate } \\
\text { discriminating } \\
\text { metabolites of SA } \\
\text { from } \\
\text { mild-to-moderate } \\
\text { asthma }\end{array}$ & $\begin{array}{l}\text { Contribution of amino acid (lysine) and lipid } \\
\text { metabolism (eicosanoids, phospholipids, and } \\
\text { unsaturated fatty acids) to asthma severity. }\end{array}$ & [190] \\
\hline $\begin{array}{l}\text { Mild asthma/HCs } \\
\qquad(n=55 / 55)\end{array}$ & NMR & $\begin{array}{l}\text { To identify } \\
\text { differential NMR } \\
\text { profiles of asthma in } \\
\text { different operating } \\
\text { temperature }(-27.3 \\
\left.\text { and }-4.8^{\circ} \mathrm{C}\right) \text { for } \\
\text { standardization of } \\
\text { EBC collection. }\end{array}$ & $\begin{array}{l}\text { Separation of asthmatics at }-27.3^{\circ} \mathrm{C} \text { from } \mathrm{HCs} \\
\text { at }-4.8^{\circ} \mathrm{C} \text { by uracil, urocanic acid, succinate, } \\
\text { SFA, Phe, hippurate, trimethylamine, Val, and } \\
\text { Tyr; from HCs at }-27.3^{\circ} \mathrm{C} \text { by propionate, } \\
4 \mathrm{OH} \text {-phenylacetate, Val, acetate, SFA, Pro, Tyr, } \\
\text { Arg, trans-aconitate, and Phe. } \\
\text { Separation of asthmatics at }-4.8^{\circ} \mathrm{C} \text { from HCs } \\
\text { at }-27.3^{\circ} \mathrm{C} \text { by Phe, succinate, Val, propionate, } \\
\text { SFA, methanol, uracil, Pro, formate, isobutyrate, } \\
\text { and urocanic acid; from } \mathrm{HCs} \text { at }-4.8^{\circ} \mathrm{C} \text { by SFA, } \\
\text { Val, adenosine, Hippurate, Ala, formate, } \\
\text { urocanic acid, Pro, acetate, ethanol, methanol, } \\
\text { and Ile. }\end{array}$ & [191] \\
\hline $\begin{array}{l}\text { Asthmatics } / \text { HCs } \\
\quad(n=89 / 20)\end{array}$ & NMR & $\begin{array}{l}\text { To determine distinct } \\
\text { metabolic patterns of } \\
\text { asthma and its } \\
\text { endotypes }\end{array}$ & $\begin{array}{l}\text { NMR spectra region at } 7 \text { ppm for distinguishing } \\
\text { asthmatics from HCs by up-regulation of } \\
\text { isopropanol and N,N, dimethylglycine and by } \\
\text { down-regulation of ammonia. } \\
\text { Classifying asthmatics as } 3 \text { clusters } \\
\text { characterized (1) by low exacerbation ratio, ( } 2) \\
\text { by high exhaled nitric oxide, and (3) by low } \\
\text { blood eosinophils but high blood neutrophils. } \\
\text { Contribution of high acetate, acetone, formic } \\
\text { acid, methanol, and N,N, dimethylglycine } \\
\text { concentrations as well as low concentrations of } \\
\text { ammonia and hydroxybutyrate to asthma } \\
\text { severity. }\end{array}$ & [192] \\
\hline $\begin{array}{c}\text { OA/LA/HCs } \\
(n=25 / 30 / 30 / 25)\end{array}$ & ${ }^{1} \mathrm{H}-\mathrm{NMR}$ & $\begin{array}{l}\text { To investigate } \\
\text { metabolic profiles } \\
\text { and pathways for } \\
\text { class-specific } \\
\text { metabolic types }\end{array}$ & $\begin{array}{l}\text { Confirmation of carbohydrate signals (3.9-3.2 } \\
\text { ppm) in OA. } \\
23 \text { and } 17 \text { metabolic pathways for OA distinct } \\
\text { from HCs and LA, respectively, mostly related } \\
\text { to energy metabolism (methane) and } \\
\text { carbohydrate metabolism } \\
\text { (glyoxylate/dicarboxylate and pyruvate). } \\
\text { Differential metabolic profiling in OA: increases } \\
\text { in glucose, butyrate, and acetoin and decreases } \\
\text { in formate, tyrosine, ethanol, ethylene glycol, } \\
\text { methanol, n-valerate, acetate, SFA, and } \\
\text { propionate compared to HCs; increases in } \\
\text { glucose, n-valerate, acetoin, isovalerate, and } \\
\text { 1,2-propanediol and decreases in formate, } \\
\text { ethnol, methanol, acetone, propionate, acetate, } \\
\text { lactate, and SFA compared to LA. }\end{array}$ & [193] \\
\hline
\end{tabular}


Table 4. Cont.

\begin{tabular}{|c|c|c|c|c|}
\hline Population & Methods & Purpose & Findings & Ref. \\
\hline \multicolumn{5}{|l|}{ Mixed } \\
\hline $\begin{array}{c}\text { OA/LA } \\
(n=11 / 22)\end{array}$ & GC-TOF-MS & $\begin{array}{l}\text { To identify } \\
\text { obesity-associated } \\
\text { metabolites for obese } \\
\text { asthma in sputum } \\
\text { and blood }\end{array}$ & $\begin{array}{l}11 \text { metabolic signatures in sputum for OA } \\
\text { related to xanthine, gluconic lactone, shikimic } \\
\text { acid, indole-3-acetate, L-glutamic acid, } \\
\text { 4-aminobutyric acid, benzoate, and } \\
\text { phytosphingosine pathways. } \\
\text { Metabolic signatures in serum of OA: increase } \\
\text { of valine, uric acid, N-Methy-DL-alanine, and } \\
\beta \text {-glycerophosphoric acid as well as decrease of } \\
\text { asparagine 1, and d-glyceric acid. } \\
3 \text { metabolic signatures in PBMCs of OA: } \\
\text { increases in 3-ydroxynorvaline } 2 \text { and decreases } \\
\text { in 3-hydroxybutyric acid, linolenic acid, and } \\
\text { isoleucine. }\end{array}$ & [184] \\
\hline
\end{tabular}

HCs, healthy controls; EA, eosinophilic asthma; NEA, non-eosinophilic asthma; OA, obese asthma; LA, lean asthma; MMA, mild-tomoderate asthma; MS, mass spectrometry; H-NMR, proton nuclear magnetic resonance; TOF, time-of-flight; HRMS, high resolution mass spectrometry; UPLC, ultra performance liquid chromatography; UHLPC, ultra high performance liquid chromatography; NICI, negative ion chemical ionization; SNP, single nucleotide polymorphism; PC.ae, acyl-alkyl-phosphatidylcholine; PC.aa, diacyl-phosphatidylcholine; SM, sphingomyelin; PSMD3, proteasome 26S subunit, non-ATPase 3; MED24, mediator complex subunit 24; TSLP, thymic stromal lymphopoietin; IL1RL1, interleukin-1 receptor-like 1; TCA, tricarboxylic acid; ICS, inhaled corticosteroid; DHEA-S, dehydroepiandrosterone sulfate; ProHyp, prolylhydroxyproline; S1P, sphinosine-1-phosphate; AMP, adenosine 5'-monohosphate; PE, phosphatidylethanolamine; SM, sphingomyelin; TG, triglyceride; PI, phosphatidylinositol; PG, phosphatidylglycerol; Cer, ceramide; LPC, lysophosphatidylcholine; $\mathrm{PGD}_{2}$, prostaglandin $\mathrm{D}_{2} ; \mathrm{PGF}_{2 \alpha}$, prostaglandin $\mathrm{F}_{2 \alpha} ; \mathrm{PGE}_{2}$, prostaglandin $\mathrm{E}_{2} ; \mathrm{CysLT}$; cysteinyl leukotriene; $\mathrm{LTE}_{4}$, leukotriene $\mathrm{E}_{4} ; \mathrm{TXA}_{2}$, thromboxane $\mathrm{A}_{2} ; \mathrm{TXB}_{2}$; thromboxane $\mathrm{B}_{2} ; \mathrm{SFA}$, saturated fatty acids; $\mathrm{PBMC}$, peripheral blood mononuclear cells.

\subsection{Limitation of "Omics" in Biomaker Identification for Asthma}

"Omics" enabled the comprehensive evaluation of holistic molecules in an organism. This advantage leads to the advances in biomarker discovery in medical fields [195]. Genomics is the first study of the omics and aims to search for genetic variants associated with specific diseases [4]. Although it has provided a comprehensive understanding for asthma, it could not explain a mild to moderate asthmatic state [196]. Moreover, the number of samples or replication tests was not sufficient [33]. In contrast, transcriptomics focuses on the differential gene expression and activity of functional genes in patients [197]. Nevertheless, DNA or mRNA expression may not represent the biological function of genes at the protein levels due to translational regulation or post-translational modification [198]. Proteomics reflects pathological changes at the time because cytokines or chemokines are important protein related to the severity of inflammatory diseases [199]. In asthma, transcriptomics and proteomics could be applicable to a wide range of cell types and biological samples including blood, BALF, sputum, and bronchial or nasal brushings [200]. However, they could not provide overall information underlying diseases due to a large variability in sample types or disease states [201]. To overcome these limitations, metabolomics was suggested as one of the latest omics technologies. In particular, its application is rapidly increasing in asthma for the detection of volatile organic compounds in EBC with a noninvasive way [202]. However, the lack of replication or standards of metabolic profiling in different biospecimens is still challenging [9]. Despite the outstanding achievements of omics studies, they are still considered insufficient to mainly be utilized in clinical practices. Therefore, the integration of multiple omics could complement the limitation of each technology.

\section{Metabolic Pathways Involved in Asthma}

\subsection{Amino Acid Metabolism}

Amino acids are involved in multiple biological functions including growth, maintenance or development, regulation of gene expression/cell signaling, and synthesis of nitrogen/protein/energy substrates for homeostasis in organisms [203]. Moreover, they are known as crucial regulators of metabolic pathways for immune responses and anti-oxidant 
activities [204]. In particular, arginine has been suggested to affect the development of asthma. It synthesizes nitric oxide (NO) by NO synthase (NOS) composed of 3 isoforms, neuronal NOS (nNOS), inducible NOS (iNOS), and endothelial NOS (eNOS) [205]. In asthmatic patients, expression of iNOS and arginase- $1 / 2$ were upregulated in the serum or epithelium and immune cells of the airways, leading to higher levels of exhaled NO and more severe symptoms [206-208]. Furthermore, arginase metabolism is involved in the regulation of T-cell function, driving Th2 airway inflammation [208]. However, suppressive roles of arginase- 2 have been reported in severe eosinophilic and neutrophilic inflammation in asthma [209]. In addition to arginine, higher levels of $\beta$-alanine [185] and lysine [190] were detected in patients with severe asthma. However, another study showed conflicting results with decreased levels of arginine, alanine, leucine, valine, and histidine in asthmatics [177]. Therefore, further studies on various phenotypes of asthma are needed to clarify with this pathway.

\subsection{Lipid Metabolism}

The importance of lipid mediators in respiratory diseases is highlighted due to their involvement in various biological functions, such as cell structural components, energy sources/metabolism, signal transduction, and material transport [210]. Among several types of lipids, fatty acids are known to be relevant to diverse mechanisms of inflammatory response in chronic airway diseases [211]. Moreover, arachidonic acids have been identified to contribute to asthma pathogenesis as precursors of eicosanoids including leukotrienes, prostaglandins, thromboxane, lipoxins, and hydroxyeicosatetraenoic acids [212]. In particular, urinary leukotriene $\mathrm{E}_{4}\left(\mathrm{LTE}_{4}\right)$ has been widely used for a diagnosis of a distinct phenotype of severe eosinophilic asthma, referred as aspirin-exacerbated respiratory disease (AERD) [213]. In addition to fatty acids, several studies reported that sphingosine-1-phosphate (S1P) levels were increased in asthmatics and correlated with asthma severity [214-216]. Furthermore, increased levels of S1P (derived from various inflammatory cells) were found in patients with AERD [217]. Despite the controversial functions of lipids, it is certain that they are key mediators in asthma pathogenesis. Therefore, lipids might be potent biomarkers for specific phenotypes of asthma and promising candidates for new therapeutic targets.

\section{Changes in Metabolite Profiles According to the Phenotype of Asthma}

\subsection{Mild-to-Moderate Asthma}

Asthma has been classified as mild, moderate, or severe types according to the severity of symptoms and frequency of asthma exacerbation. Mild-to-moderate asthma can be defined as a controlled one by step 1-4 treatments [218]. Several studies have performed metabolic analyses to identify metabolic determinants related to the severity of asthma. As a result, increased 8 ( $\alpha$-linolenic acid, linoleic acid, oleic acid, linoleoyl ethanolamide, dodecanedioic acid, linoleates, methylcysteine, and theobromine) and decreased 6 metabolites (indole-3-acetate, lysine, lyso-platelet activating factor C16:0, methionine, phenylalanine, and phenylacetyl glutamine) were identified in metabolic profiles of mild asthmatics compared to healthy controls [179]. In addition, lipidomic analysis found lipid metabolism dysregulation in moderate asthma positively correlated with asthma severity, but not in mild asthma when compared to healthy controls [183].

\subsection{Severe Asthma}

According to the GINA guidelines, severe asthma (SA) is characterized by uncontrolled or partially controlled symptoms, despite consistent demands for high-dose inhaled corticosteroids (ICSs) with an additional controller or oral corticosteroids (OCSs) [218]. Metabolic analysis in SA found significant differences of metabolites, especially in amino acid metabolism with higher levels of $\beta$-alanine [182] or lysine [190]. Moreover, a lipidomic analysis revealed that 22 metabolites are changed in SA. Several lipid mediators, including sphingolipids (sphingomyelin, ceramide, and S1P), free fatty acids, and eicosanoids ( LTE $_{4}$ ) 
are positively correlated with asthma severity $[179,186]$. In addition, the resistance to steroids is one of the clinical characteristics in SA [219]. In particular, distinct metabolic profiles are noted in severe asthmatics using ICSs or OCSs with decreased steroid metabolites. Moreover, linoleic acids from polyunsaturated fatty acids drive steroid refractory response and contribute to asthma severity with airway epithelial injury [220,221].

\subsection{Obese Asthma}

Obese asthma is classified as a distinct phenotype of asthma with persistent symptoms and resistance to conventional medication [222]. With the increasing of the obese population, obesity now accounts for $11 \%$ of adult asthmatics [223]. Although obesity is one of the risk factors for asthma, the mechanisms are poorly understood and needed to be clarified [224]. Several studies have suggested that the metabolic dysregulation is related to development and progress of asthma [225,226]. With omics technologies, distinct metabolic changes have been identified in obese subjects [227]. In particular, high-fat diets tend to increase the concentrations of ceramide, sphingomyelin, and S1P in multiple tissue and organs [228]. Among them, ceramide could contribute to airway hyperresponsiveness, suggesting a possible correlation with asthma severity [229]. Moreover, elevated levels of C18:0 and C:20 were found in the sera of obese asthmatics [230]. Although the exact mechanisms are not comprehended yet, clinical and experimental research have suggested the specific metabolic changes in obese asthma.

\section{Clinical Implications and Perspectives of Various Metabolites}

Due to the sensitivity to biological alterations, metabolites can serve to search for novel biomarkers and pathological mechanisms for asthma phenotypes (Table 5). The application of metabolomic analysis provides new insights into the classification of asthma phenotypes in terms of the dynamic network between genetic and environmental factors [6]. In addition, the integrated omics has been used from early diagnosis to monitoring treatment response in diseases [231]. Therefore, metabolomics may lead to a precise discrimination of asthmatic patients, but also improvement in a search for new therapeutic targets in asthma as well [232]. Furthermore, the metabolic therapy is a novel concept comprising restrictive diet control or nutritional supplements with relatively easy and safe interventions. Although metabolomics is highlighted for biomarker identification for asthma, the efficacy and safety of metabolic signatures should be validated for their practical uses in clinical courses. Based on integrative omics studies in asthma, metabolites may realize the implementation of personalized medication and expand treatment options for asthmatics in a combination with current medications.

Table 5. Metabolic signatures for asthma and its phenotypes.

\begin{tabular}{|c|c|c|c|c|}
\hline Significant Metabolic Signatures & $\begin{array}{l}\text { Population or } \\
\text { Phenotype }\end{array}$ & Sample & AUC Values & Ref. \\
\hline \multicolumn{5}{|l|}{ Carbohydrates } \\
\hline \multirow{2}{*}{ Glucose } & $\mathrm{A} / \mathrm{H}$ & serum, $\downarrow$ & & [177] \\
\hline & $\mathrm{O}>\mathrm{L} / \mathrm{ON}$ & EBC & & [193] \\
\hline Monosaccharide & $\mathrm{N}>\mathrm{E}>\mathrm{H}$ & serum & & [180] \\
\hline Maltose & $\mathrm{A} / \mathrm{H}$ & plasma, $\uparrow$ & & [182] \\
\hline Maltotriose & $\mathrm{A} / \mathrm{H}$ & plasma, $\uparrow$ & & [182] \\
\hline D-Glyceric acid & $\mathrm{O}<\mathrm{L}$ & serum & & [184] \\
\hline D-Glucoheptose 1 & $\mathrm{O}>\mathrm{L}$ & sputum & & [184] \\
\hline \multicolumn{5}{|l|}{ Amino acid Metabolism } \\
\hline Alanine & $\mathrm{A} / \mathrm{H}$ & $\mathrm{EBC}, \uparrow$ & & [191] \\
\hline N-Methyl-DL-alanine & $\mathrm{O}>\mathrm{L}$ & serum & & [184] \\
\hline
\end{tabular}


Table 5. Cont.

\begin{tabular}{|c|c|c|c|c|c|}
\hline \multicolumn{2}{|c|}{ Significant Metabolic Signatures } & $\begin{array}{l}\text { Population or } \\
\text { Phenotype }\end{array}$ & Sample & AUC Values & Ref. \\
\hline \multirow{2}{*}{\multicolumn{2}{|c|}{ Arginine }} & $\mathrm{A} / \mathrm{H}$ & serum, $\downarrow$ & & [177] \\
\hline & & $\mathrm{A} / \mathrm{H}$ & $\mathrm{EBC}, \uparrow$ & & [191] \\
\hline \multicolumn{2}{|l|}{ Glutamine } & $\mathrm{A} / \mathrm{H}$ & serum, $\uparrow$ & & [177] \\
\hline \multicolumn{2}{|c|}{ L-glutamic acid } & $\mathrm{O}>\mathrm{L}$ & sputum & & [184] \\
\hline \multicolumn{2}{|c|}{$\beta$-glutamic acid 1} & $\mathrm{O}>\mathrm{L}$ & sputum & & [184] \\
\hline \multicolumn{2}{|l|}{ Histidine } & $\mathrm{A} / \mathrm{H}$ & serum, $\downarrow$ & & [177] \\
\hline \multirow{2}{*}{\multicolumn{2}{|c|}{ Isoleucine }} & $\mathrm{O}<\mathrm{L}$ & PBMCs & & [184] \\
\hline & & $\mathrm{A} / \mathrm{H}$ & $\mathrm{EBC}, \uparrow$ & & [191] \\
\hline \multicolumn{2}{|l|}{ Methionine } & $\mathrm{A} / \mathrm{H}$ & serum, $\uparrow$ & & [177] \\
\hline \multicolumn{2}{|l|}{ Phenylalanine } & $\mathrm{A} / \mathrm{H}$ & $\mathrm{EBC}, \uparrow$ & & [191] \\
\hline \multicolumn{2}{|l|}{ Proline } & $\mathrm{A} / \mathrm{H}$ & $\mathrm{EBC}, \uparrow$ & & [191] \\
\hline \multirow{2}{*}{\multicolumn{2}{|c|}{ Tyrosine }} & $\mathrm{A} / \mathrm{H}$ & $\mathrm{EBC}, \downarrow$ & & [191] \\
\hline & & $\mathrm{O}<\mathrm{L} / \mathrm{ON}$ & EBC & & [193] \\
\hline \multirow{2}{*}{\multicolumn{2}{|c|}{ Valine }} & $\mathrm{O}>\mathrm{L}$ & serum & & [184] \\
\hline & & $\mathrm{A} / \mathrm{H}$ & $\mathrm{EBC}, \downarrow$ & & [191] \\
\hline \multicolumn{2}{|l|}{ Taurine } & $\mathrm{A} / \mathrm{H}$ & plasma, $\uparrow$ & & [182] \\
\hline \multicolumn{2}{|l|}{ Gly-pro } & $\mathrm{O}>\mathrm{L}$ & sputum & & [184] \\
\hline \multicolumn{2}{|c|}{ 5-Aminobaleric acid } & $\mathrm{A} / \mathrm{H}$ & serum, $\uparrow$ & 0.948 & [178] \\
\hline \multicolumn{2}{|c|}{ N,N-Dimethylglycine } & $\mathrm{A} / \mathrm{H}$ & $\mathrm{EBC}, \uparrow$ & & [192] \\
\hline \multicolumn{2}{|c|}{ 3-Hydroxynorvaline 2} & $\mathrm{O}<\mathrm{L}$ & PBMCs & & [184] \\
\hline \multicolumn{6}{|c|}{ Lipid metabolism } \\
\hline \multicolumn{2}{|l|}{ Choline } & $\mathrm{A} / \mathrm{H}$ & serum, $\downarrow$ & & [177] \\
\hline \multirow{17}{*}{ Glycerolipids } & Phosphatidylcholine (20:4/16:1) & $\mathrm{H}>\mathrm{N}>\mathrm{E}$ & serum & & [180] \\
\hline & Phosphatidylcholine (18:1/2:0) & $\mathrm{N}>\mathrm{E}>\mathrm{H}$ & serum & & [180] \\
\hline & Phosphatidylcholine (16:0/18:1) & $\mathrm{E}>\mathrm{N}>\mathrm{H}$ & serum & & [180] \\
\hline & Acyl-alkyl-phosphatidylcholine (C42:4) & $\mathrm{A} / \mathrm{H}$ & serum, $\uparrow$ & & [176] \\
\hline & Acyl-alkyl-phosphatidylcholine (C42:5) & $\mathrm{A} / \mathrm{H}$ & serum, $\uparrow$ & & [176] \\
\hline & Acyl-alkyl-phosphatidylcholine (C44:5) & $\mathrm{A} / \mathrm{H}$ & serum, $\uparrow$ & & [176] \\
\hline & Acyl-alkyl-phosphatidylcholine (C44:6) & $\mathrm{A} / \mathrm{H}$ & serum, $\uparrow$ & & [176] \\
\hline & Phosphatidylethanolamine & $\mathrm{A} / \mathrm{H}$ & plasma, $\uparrow$ & & [182] \\
\hline & Phosphatidylethanolamine (38:1) & $\mathrm{A} / \mathrm{H}$ & plasma, $\uparrow$ & 0.746 & [183] \\
\hline & Phosphatidylethanolamine $(18: 1 \mathrm{p} / 22: 6)$ & $\mathrm{A} / \mathrm{H}$ & plasma, $\uparrow$ & 0.731 & [183] \\
\hline & Phosphatidylethanolamine (20:0/18:1) & $\mathrm{A} / \mathrm{H}$ & plasma, $\uparrow$ & 0.710 & [183] \\
\hline & Phosphatidylethanolamine (18:3/14:0) & $\mathrm{E}>\mathrm{N}>\mathrm{H}$ & serum & & [180] \\
\hline & Phosphatidylglycerol (44:0) & $\mathrm{A} / \mathrm{H}$ & plasma, $\downarrow$ & 0.675 & [183] \\
\hline & Glycerophosphorylcholine & $\mathrm{A} / \mathrm{H}$ & plasma, $\uparrow$ & & [182] \\
\hline & & $\mathrm{H}>\mathrm{N}>\mathrm{E}$ & serum & & [180] \\
\hline & B-glycerophosphorate & $\mathrm{O}>\mathrm{L}$ & serum & & [184] \\
\hline & Lysophosphatidylcholine (18:1) & $\mathrm{E}>\mathrm{N}>\mathrm{H}$ & serum & & [180] \\
\hline
\end{tabular}


Table 5. Cont.

\begin{tabular}{|c|c|c|c|c|c|}
\hline \multicolumn{2}{|c|}{ Significant Metabolic Signatures } & \multirow{2}{*}{$\begin{array}{l}\text { Population or } \\
\text { Phenotype }\end{array}$} & \multirow{2}{*}{$\begin{array}{l}\text { Sample } \\
\text { plasma, } \downarrow\end{array}$} & \multirow{2}{*}{$\begin{array}{l}\text { AUC Values } \\
0.689\end{array}$} & \multirow{2}{*}{$\begin{array}{l}\text { Ref. } \\
{[183]}\end{array}$} \\
\hline & Lysophosphatidylcholine (22:4) & & & & \\
\hline & Phosphatidylinositol & $\mathrm{A} / \mathrm{H}$ & plasma, $\downarrow$ & 0.723 & [183] \\
\hline & Triglyceride (17:0/18:0/18:0) & $\mathrm{A} / \mathrm{H}$ & plasma, $\uparrow$ & 0.714 & [183] \\
\hline & Triglyceride (16:0/16:0/18:1) & $\mathrm{A} / \mathrm{H}$ & plasma, $\uparrow$ & 0.661 & [183] \\
\hline & O-phosphocholine & $\mathrm{A} / \mathrm{H}$ & serum, $\downarrow$ & & [177] \\
\hline \multirow{11}{*}{ Fatty acids } & \multirow{2}{*}{ Saturated fatty acid } & $\mathrm{A} / \mathrm{H}$ & $\mathrm{EBC}, \downarrow$ & & [191] \\
\hline & & $\mathrm{O}<\mathrm{L} / \mathrm{ON}$ & $\mathrm{EBC}$ & & [193] \\
\hline & Arachidonic acid & $\mathrm{N}>\mathrm{E}>\mathrm{H}$ & serum & & [180] \\
\hline & Arachidonate (20:4n6) & $\mathrm{A} / \mathrm{H}$ & plasma, $\uparrow$ & & [182] \\
\hline & Isobutyrate & $\mathrm{A} / \mathrm{H}$ & $\mathrm{EBC}, \uparrow$ & & [191] \\
\hline & Linolenic acid & $\mathrm{O}<\mathrm{L}$ & PBMCs & & [184] \\
\hline & N-palmitoyltaurine & SA & serum, $\downarrow$ & & [179] \\
\hline & Oleamide & $\mathrm{A} / \mathrm{H}$ & plasma, $\downarrow$ & & [182] \\
\hline & \multirow{2}{*}{ n-valerate } & $\mathrm{O}>\mathrm{L}$ & EBC & & [193] \\
\hline & & $\mathrm{O}<\mathrm{ON}$ & $\mathrm{EBC}$ & & [193] \\
\hline & Isovalerate & $\mathrm{O}>\mathrm{L}$ & $\mathrm{EBC}$ & & [193] \\
\hline \multirow{7}{*}{ Sphingolipids } & Sphingosine & $\mathrm{A} / \mathrm{H}$ & plasma, $\uparrow$ & & [182] \\
\hline & Sphingosine-1-phosphate & SA & serum, $\uparrow$ & & [179] \\
\hline & Sphingomyelin (d18:1/18:1) & $\mathrm{A} / \mathrm{H}$ & plasma, $\uparrow$ & 0.731 & [183] \\
\hline & Phytosphingosine & $\mathrm{H}>\mathrm{N}>\mathrm{E}$ & serum & & [180] \\
\hline & Phytosphingosine 2 & $\mathrm{O}>\mathrm{L}$ & sputum & & [184] \\
\hline & Sphinganine & $\mathrm{H}>\mathrm{N}>\mathrm{E}$ & serum & & [180] \\
\hline & Ceramide (d16:0/27:2) & $\mathrm{A} / \mathrm{H}$ & plasma, $\downarrow$ & 0.690 & [183] \\
\hline \multirow{5}{*}{ Eicosanoids } & Leukotriene $\mathrm{E}_{4}$ & SA, T2 & urine, $\uparrow$ & & [187] \\
\hline & Tetranor prostaglandin D metabolites & SA, T2 & urine, $\uparrow$ & & [187] \\
\hline & 2,3-dinor-11 $\beta$-PGF $2 \alpha$ & $\mathrm{SA}, \mathrm{T} 2$ & urine, $\uparrow$ & & [187] \\
\hline & 8-iso-PGF $2 \alpha$ & SA & urine, $\uparrow$ & & [187] \\
\hline & 2,3-dinor-8-iso-PGF $2 \alpha$ & SA & urine, $\uparrow$ & & [187] \\
\hline \multirow{6}{*}{ Sterol/Steroids } & Androsterone sulfate & $\mathrm{A} / \mathrm{H}$ & plasma, $\downarrow$ & & [182] \\
\hline & Epiandrosterone sulfate & $\mathrm{A} / \mathrm{H}$ & plasma, $\downarrow$ & & [182] \\
\hline & Dehydroepiandrosterone sulfate & SA & serum, $\downarrow$ & & [179] \\
\hline & Glycodeoxycholate & $\mathrm{A} / \mathrm{H}$ & plasma, $\uparrow$ & & [182] \\
\hline & Taurocholate & $\mathrm{A} / \mathrm{H}$ & plasma, $\uparrow$ & & [182] \\
\hline & Lathosterol & $\mathrm{A} / \mathrm{H}$ & plasma, $\uparrow$ & & [182] \\
\hline Retinol & & $\mathrm{H}>\mathrm{N}>\mathrm{E}$ & serum & & [180] \\
\hline \multicolumn{6}{|l|}{ Carboxylic acid } \\
\hline \multirow{3}{*}{ Acetate } & & $\mathrm{A} / \mathrm{H}$ & serum, $\downarrow$ & & [180] \\
\hline & & $\mathrm{A} / \mathrm{H}$ & $\mathrm{EBC}, \uparrow / \downarrow$ & & [180] \\
\hline & & $\mathrm{O}<\mathrm{L} / \mathrm{ON}$ & $\mathrm{EBC}$ & & [180] \\
\hline
\end{tabular}


Table 5. Cont.

\begin{tabular}{|c|c|c|c|c|c|}
\hline \multicolumn{2}{|c|}{ Significant Metabolic Signatures } & $\begin{array}{l}\text { Population or } \\
\text { Phenotype }\end{array}$ & Sample & AUC Values & Ref. \\
\hline \multirow{2}{*}{\multicolumn{2}{|c|}{ Butyrate }} & $\mathrm{A} / \mathrm{H}$ & $\mathrm{EBC}, \uparrow$ & & [180] \\
\hline & & $\mathrm{O}>\mathrm{ON}$ & EBC & & [180] \\
\hline \multirow{3}{*}{\multicolumn{2}{|c|}{ Formate }} & $\mathrm{A} / \mathrm{H}$ & serum, $\downarrow$ & & [180] \\
\hline & & $\mathrm{A} / \mathrm{H}$ & $\mathrm{EBC}, \downarrow$ & & [180] \\
\hline & & $\mathrm{O}<\mathrm{L} / \mathrm{ON}$ & EBC & & [180] \\
\hline \multirow{2}{*}{\multicolumn{2}{|c|}{ Propionate }} & $\mathrm{A} / \mathrm{H}^{\prime}$ & $\mathrm{EBC}, \uparrow$ & & [180] \\
\hline & & $\mathrm{O}<\mathrm{L} / \mathrm{ON}$ & $\mathrm{EBC}$ & & [180] \\
\hline \multicolumn{6}{|l|}{ TCA cycle } \\
\hline \multirow{2}{*}{\multicolumn{2}{|c|}{ Succinic acid }} & $\mathrm{A} / \mathrm{H}$ & serum, $\uparrow$ & \multirow{2}{*}{0.976} & [191] \\
\hline & & $\mathrm{A} / \mathrm{H}$ & $\mathrm{EBC}, \uparrow / \downarrow$ & & [191] \\
\hline \multicolumn{6}{|c|}{ Nucleoside/Nucleotide } \\
\hline \multicolumn{2}{|l|}{ Inosine } & $\mathrm{A} / \mathrm{H}$ & serum, $\uparrow$ & 0.962 & [178] \\
\hline \multicolumn{2}{|l|}{ Adenosine } & $\mathrm{A} / \mathrm{H}$ & $\mathrm{EBC}, \downarrow$ & & [191] \\
\hline \multicolumn{6}{|c|}{ Other organic compounds } \\
\hline \multicolumn{2}{|l|}{ Acetoin } & $\mathrm{O}>\mathrm{L} / \mathrm{ON}$ & EBC & & [193] \\
\hline \multirow{9}{*}{ Alcohol } & Ethanol & $\mathrm{A} / \mathrm{H}$ & $\mathrm{EBC}, \uparrow$ & & [191] \\
\hline & & $\mathrm{O}<\mathrm{L} / \mathrm{ON}$ & EBC & & [193] \\
\hline & Ethylene glycol & $\mathrm{O}<\mathrm{ON}$ & $\mathrm{EBC}$ & & [193] \\
\hline & Isopropanol & $\mathrm{A} / \mathrm{H}$ & $\mathrm{EBC}, \uparrow$ & & [192] \\
\hline & \multirow{4}{*}{ Methanol } & $\mathrm{A} / \mathrm{H}$ & serum, $\downarrow$ & & [177] \\
\hline & & $\mathrm{A} / \mathrm{H}$ & $\mathrm{EBC}, \uparrow$ & & [177] \\
\hline & & $\mathrm{A} / \mathrm{H}$ & $\mathrm{EBC}, \uparrow$ & & [191] \\
\hline & & $\mathrm{O}<\mathrm{L} / \mathrm{ON}$ & EBC & & [191] \\
\hline & 1,2-propanediol & $\mathrm{O}>\mathrm{L}$ & $\mathrm{EBC}$ & & [193] \\
\hline Amines & Trimethylamine & $\mathrm{A} / \mathrm{H}$ & $\mathrm{EBC}, \downarrow$ & & [191] \\
\hline Ascorbate & & $\mathrm{A} / \mathrm{H}$ & serum, $\uparrow$ & 0.917 & [178] \\
\hline 3-aminopropioni & & $\mathrm{O}>\mathrm{L}$ & sputum & & [184] \\
\hline \multirow{2}{*}{ Benzene } & 3,4-Dihydroxybenzoic acid & $\mathrm{A} / \mathrm{H}$ & serum, $\uparrow$ & 0.965 & [178] \\
\hline & Hippurate & $\mathrm{A} / \mathrm{H}$ & $\mathrm{EBC}, \downarrow$ & & [191] \\
\hline \multicolumn{2}{|c|}{ 3-Hydroxybutyric acid } & $\mathrm{O}>\mathrm{L}$ & sputum & & [184] \\
\hline \multirow{3}{*}{ Ketones bodies } & \multirow{2}{*}{ Acetone } & $\mathrm{A} / \mathrm{H}$ & serum, $\downarrow$ & & [177] \\
\hline & & $\mathrm{O}<\mathrm{L}$ & EBC & & [193] \\
\hline & 2-Ketovaleric acid & $\mathrm{A} / \mathrm{H}$ & serum, $\uparrow$ & 0.874 & [178] \\
\hline \multicolumn{2}{|l|}{ Lactate } & $\mathrm{O}<\mathrm{L}$ & EBC & & [193] \\
\hline \multicolumn{2}{|l|}{ Urocanic acid } & $\mathrm{A} / \mathrm{H}$ & $\mathrm{EBC}, \downarrow$ & & [191] \\
\hline \multicolumn{2}{|c|}{ Dehydroascorbic acid } & $\mathrm{A} / \mathrm{H}$ & serum, $\uparrow$ & 0.896 & [178] \\
\hline \multirow{2}{*}{\multicolumn{2}{|c|}{ Urea }} & $\mathrm{A} / \mathrm{H}$ & plasma, $\downarrow$ & & [182] \\
\hline & & $\mathrm{A} / \mathrm{H}$ & $\mathrm{EBC}, \uparrow$ & & [192] \\
\hline \multicolumn{2}{|l|}{ Uric acid } & $\mathrm{O}>\mathrm{L}$ & serum, $\uparrow$ & & [184] \\
\hline
\end{tabular}


Table 5. Cont.

\begin{tabular}{llll}
\hline Significant Metabolic Signatures & $\begin{array}{l}\text { Population or } \\
\text { Phenotype }\end{array}$ & Sample AUC Values Ref. & Aputum \\
\hline Xanthine & $\mathrm{O}>\mathrm{L}$ & & \\
\hline Inorganic compounds & & EBC, $\downarrow$ & [184] \\
\hline Ammonia & $\mathrm{A} / \mathrm{H}$ & $\mathrm{sputum}$ & O192] \\
\hline Pyrophosphate-3 & $\mathrm{O}>\mathrm{L}$ & $184]$ \\
\hline
\end{tabular}

A, asthmatics; H, healthy controls; O, obese asthmatics; L, lean asthmatics; ON, obese non-asthmatics; E, eosinophilic asthma; N, non-eosinophilic asthma; SA, severe asthma; T2, type 2 inflammation marker; $\downarrow$, lower in asthma; $\uparrow$, higher in asthma.

Author Contributions: S.S. wrote the paper and created the tables. Y.C. revised the manuscript. H.-S.P. provided overall supervision for the entire study. All authors have read and agreed to the published version of the manuscript.

Funding: The work was supported by the Korean Health Technology R \& D Project through the Korea Health Industry Development Institute (KHIDI) grant funded by the Ministry of Health and Welfare, Republic of Korea (HR16C0001). This research received no external funding.

Conflicts of Interest: The authors declare no competing financial interest.

\section{References}

1. Kuruvilla, M.E.; Lee, F.E.; Lee, G.B. Understanding Asthma Phenotypes, Endotypes, and Mechanisms of Disease. Clin. Rev. Allergy Immunol. 2019, 56, 219-233. [CrossRef] [PubMed]

2. Miller, R.L.; Ho, S.M. Environmental epigenetics and asthma: Current concepts and call for studies. Am. J. Respir. Crit. Care Med. 2008, 177, 567-573. [CrossRef] [PubMed]

3. Carr, T.F.; Zeki, A.A.; Kraft, M. Eosinophilic and Noneosinophilic Asthma. Am. J. Respir. Crit. Care Med. 2018, 197, 22-37. [CrossRef] [PubMed]

4. Hasin, Y.; Seldin, M.; Lusis, A. Multi-omics approaches to disease. Genome Biol. 2017, 18, 83. [CrossRef]

5. Zhang, A.; Sun, H.; Wang, X. Saliva metabolomics opens door to biomarker discovery, disease diagnosis, and treatment. Appl. Biochem. Biotechnol. 2012, 168, 1718-1727. [CrossRef]

6. Johnson, C.H.; Ivanisevic, J.; Siuzdak, G. Metabolomics: Beyond biomarkers and towards mechanisms. Nat. Rev. Mol. Cell Biol. 2016, 17, 451-459. [CrossRef]

7. Zhang, A.; Sun, H.; Yan, G.; Wang, P.; Wang, X. Metabolomics for Biomarker Discovery: Moving to the Clinic. BioMed Res. Int. 2015, 2015, 354671. [CrossRef]

8. Karczewski, K.J.; Snyder, M.P. Integrative omics for health and disease. Nat. Rev. Genet. 2018, 19, 299-310. [CrossRef]

9. Kelly, R.S.; Dahlin, A.; McGeachie, M.J.; Qiu, W.; Sordillo, J.; Wan, E.S.; Wu, A.C.; Lasky-Su, J. Asthma Metabolomics and the Potential for Integrative Omics in Research and the Clinic. Chest 2017, 151, 262-277. [CrossRef]

10. Thomsen, S.F.; van der Sluis, S.; Kyvik, K.O.; Skytthe, A.; Backer, V. Estimates of asthma heritability in a large twin sample. Clin. Exp. Allergy 2010, 40, 1054-1061. [CrossRef]

11. Dold, S.; Wjst, M.; von Mutius, E.; Reitmeir, P.; Stiepel, E. Genetic risk for asthma, allergic rhinitis, and atopic dermatitis. Arch. Dis. Child. 1992, 67, 1018-1022. [CrossRef]

12. El-Husseini, Z.W.; Gosens, R.; Dekker, F.; Koppelman, G.H. The genetics of asthma and the promise of genomics-guided drug target discovery. Lancet Respir. Med. 2020, 8, 1045-1056. [CrossRef]

13. Bush, W.S.; Moore, J.H. Chapter 11: Genome-wide association studies. PLoS Comput. Biol. 2012, 8, e1002822. [CrossRef]

14. Willis-Owen, S.A.G.; Cookson, W.O.C.; Moffatt, M.F. The Genetics and Genomics of Asthma. Annu. Rev. Genom. Hum. Genet. 2018, 19, 223-246. [CrossRef]

15. Weinhold, B. Epigenetics: The science of change. Environ. Health Perspect 2006, 114, A160-A167. [CrossRef]

16. Brand, S.; Kesper, D.A.; Teich, R.; Kilic-Niebergall, E.; Pinkenburg, O.; Bothur, E.; Lohoff, M.; Garn, H.; Pfefferle, P.I.; Renz, H. DNA methylation of TH1/TH2 cytokine genes affects sensitization and progress of experimental asthma. J. Allergy Clin. Immunol. 2012, 129, 1602-1610.e6. [CrossRef]

17. Gunawardhana, L.P.; Gibson, P.G.; Simpson, J.L.; Benton, M.C.; Lea, R.A.; Baines, K.J. Characteristic DNA methylation profiles in peripheral blood monocytes are associated with inflammatory phenotypes of asthma. Epigenetics 2014, 9, 1302-1316. [CrossRef]

18. Deaton, A.M.; Webb, S.; Kerr, A.R.; Illingworth, R.S.; Guy, J.; Andrews, R.; Bird, A. Cell type-specific DNA methylation at intragenic CpG islands in the immune system. Genome Res. 2011, 21, 1074-1086. [CrossRef]

19. Baxi, S.N.; Phipatanakul, W. The role of allergen exposure and avoidance in asthma. Adolesc Med. State Art Rev. 2010, 21, 57-71, viii-ix.

20. Platts-Mills, T.; Leung, D.Y.; Schatz, M. The role of allergens in asthma. Am. Fam. Physician 2007, 76, 675-680. 
21. Holt, P.G.; Macaubas, C.; Stumbles, P.A.; Sly, P.D. The role of allergy in the development of asthma. Nature 1999, 402, B12-B17. [CrossRef] [PubMed]

22. Wenzel, S.E. Asthma phenotypes: The evolution from clinical to molecular approaches. Nat. Med. 2012, 18, 716-725. [CrossRef] [PubMed]

23. Guarnieri, M.; Balmes, J.R. Outdoor air pollution and asthma. Lancet 2014, 383, 1581-1592. [CrossRef]

24. Orellano, P.; Quaranta, N.; Reynoso, J.; Balbi, B.; Vasquez, J. Effect of outdoor air pollution on asthma exacerbations in children and adults: Systematic review and multilevel meta-analysis. PLoS ONE 2017, 12, e0174050. [CrossRef]

25. Van Eerdewegh, P.; Little, R.D.; Dupuis, J.; Del Mastro, R.G.; Falls, K.; Simon, J.; Torrey, D.; Pandit, S.; McKenny, J.; Braunschweiger, K.; et al. Association of the ADAM33 gene with asthma and bronchial hyperresponsiveness. Nature 2002, 418, 426-430. [CrossRef]

26. Allen, M.; Heinzmann, A.; Noguchi, E.; Abecasis, G.; Broxholme, J.; Ponting, C.P.; Bhattacharyya, S.; Tinsley, J.; Zhang, Y.; Holt, R.; et al. Positional cloning of a novel gene influencing asthma from chromosome 2q14. Nat. Genet. 2003, 35, 258-263. [CrossRef]

27. Zhang, Y.; Leaves, N.I.; Anderson, G.G.; Ponting, C.P.; Broxholme, J.; Holt, R.; Edser, P.; Bhattacharyya, S.; Dunham, A.; Adcock, I.M.; et al. Positional cloning of a quantitative trait locus on chromosome 13q14 that influences immunoglobulin E levels and asthma. Nat. Genet. 2003, 34, 181-186. [CrossRef]

28. Laitinen, T.; Polvi, A.; Rydman, P.; Vendelin, J.; Pulkkinen, V.; Salmikangas, P.; Makela, S.; Rehn, M.; Pirskanen, A.; Rautanen, A.; et al. Characterization of a common susceptibility locus for asthma-related traits. Science 2004, 304, 300-304. [CrossRef]

29. Nicolae, D.; Cox, N.J.; Lester, L.A.; Schneider, D.; Tan, Z.; Billstrand, C.; Kuldanek, S.; Donfack, J.; Kogut, P.; Patel, N.M.; et al. Fine mapping and positional candidate studies identify HLA-G as an asthma susceptibility gene on chromosome 6p21. Am. J. Hum. Genet. 2005, 76, 349-357. [CrossRef]

30. Noguchi, E.; Yokouchi, Y.; Zhang, J.; Shibuya, K.; Shibuya, A.; Bannai, M.; Tokunaga, K.; Doi, H.; Tamari, M.; Shimizu, M.; et al. Positional identification of an asthma susceptibility gene on human chromosome 5q33. Am. J. Respir. Crit. Care Med. 2005, 172, 183-188. [CrossRef]

31. Balaci, L.; Spada, M.C.; Olla, N.; Sole, G.; Loddo, L.; Anedda, F.; Naitza, S.; Zuncheddu, M.A.; Maschio, A.; Altea, D.; et al. IRAK-M is involved in the pathogenesis of early-onset persistent asthma. Am. J. Hum. Genet. 2007, 80, 1103-1114. [CrossRef]

32. White, J.H.; Chiano, M.; Wigglesworth, M.; Geske, R.; Riley, J.; White, N.; Hall, S.; Zhu, G.; Maurio, F.; Savage, T.; et al. Identification of a novel asthma susceptibility gene on chromosome 1qter and its functional evaluation. Hum. Mol. Genet. 2008, 17, 1890-1903. [CrossRef]

33. Hoffjan, S.; Nicolae, D.; Ober, C. Association studies for asthma and atopic diseases: A comprehensive review of the literature. Respir. Res. 2003, 4, 14. [CrossRef]

34. Moffatt, M.F.; Gut, I.G.; Demenais, F.; Strachan, D.P.; Bouzigon, E.; Heath, S.; von Mutius, E.; Farrall, M.; Lathrop, M.; Cookson, W.; et al. A large-scale, consortium-based genomewide association study of asthma. N. Engl. J. Med. 2010, 363, 1211-1221. [CrossRef]

35. Torgerson, D.G.; Ampleford, E.J.; Chiu, G.Y.; Gauderman, W.J.; Gignoux, C.R.; Graves, P.E.; Himes, B.E.; Levin, A.M.; Mathias, R.A.; Hancock, D.B.; et al. Meta-analysis of genome-wide association studies of asthma in ethnically diverse North American populations. Nat. Genet. 2011, 43, 887-892. [CrossRef]

36. Kim, K.W.; Ober, C. Lessons Learned From GWAS of Asthma. Allergy Asthma Immunol. Res. 2019, 11, 170-187. [CrossRef]

37. Bourgain, C.; Hoffjan, S.; Nicolae, R.; Newman, D.; Steiner, L.; Walker, K.; Reynolds, R.; Ober, C.; McPeek, M.S. Novel case-control test in a founder population identifies P-selectin as an atopy-susceptibility locus. Am. J. Hum. Genet. 2003, 73, 612-626. [CrossRef]

38. Mao, X.Q.; Kawai, M.; Yamashita, T.; Enomoto, T.; Dake, Y.; Sasaki, S.; Kataoka, Y.; Fukuzumi, T.; Endo, K.; Sano, H.; et al. Imbalance production between interleukin-1beta (IL-1beta) and IL-1 receptor antagonist (IL-1Ra) in bronchial asthma. Biochem. Biophys. Res. Commun. 2000, 276, 607-612. [CrossRef]

39. Karjalainen, J.; Nieminen, M.M.; Aromaa, A.; Klaukka, T.; Hurme, M. The IL-1beta genotype carries asthma susceptibility only in men. J. Allergy Clin. Immunol. 2002, 109, 514-516. [CrossRef]

40. Yan, L.; Galinsky, R.E.; Bernstein, J.A.; Liggett, S.B.; Weinshilboum, R.M. Histamine N-methyltransferase pharmacogenetics: Association of a common functional polymorphism with asthma. Pharmacogenetics 2000, 10, 261-266. [CrossRef]

41. Howard, T.D.; Postma, D.S.; Hawkins, G.A.; Koppelman, G.H.; Zheng, S.L.; Wysong, A.K.; Xu, J.; Meyers, D.A.; Bleecker, E.R. Fine mapping of an IgE-controlling gene on chromosome 2q: Analysis of CTLA4 and CD28. J. Allergy Clin. Immunol. 2002, 110, 743-751. [CrossRef]

42. Fukunaga, K.; Asano, K.; Mao, X.Q.; Gao, P.S.; Roberts, M.H.; Oguma, T.; Shiomi, T.; Kanazawa, M.; Adra, C.N.; Shirakawa, T.; et al. Genetic polymorphisms of CC chemokine receptor 3 in Japanese and British asthmatics. Eur. Respir. J. 2001, 17, 59-63. [CrossRef]

43. Hall, I.P.; Wheatley, A.; Christie, G.; McDougall, C.; Hubbard, R.; Helms, P.J. Association of CCR5 $\triangle 32$ with reduced risk of asthma. Lancet 1999, 354, 1264-1265. [CrossRef]

44. McGinnis, R.; Child, F.; Clayton, S.; Davies, S.; Lenney, W.; Illig, T.; Wjst, M.; Spurr, N.; Debouck, C.; Hajeer, A.H.; et al. Further support for the association of CCR5 allelic variants with asthma susceptibility. Eur. J. Immunogenet. 2002, 29, 525-528. [CrossRef]

45. Lazarus, R.; Klimecki, W.T.; Raby, B.A.; Vercelli, D.; Palmer, L.J.; Kwiatkowski, D.J.; Silverman, E.K.; Martinez, F.; Weiss, S.T. Single-nucleotide polymorphisms in the Toll-like receptor 9 gene (TLR9): Frequencies, pairwise linkage disequilibrium, and haplotypes in three U.S. ethnic groups and exploratory case-control disease association studies. Genomics 2003, 81, 85-91. [CrossRef] 
46. Kirkbride, H.J.; Bolscher, J.G.; Nazmi, K.; Vinall, L.E.; Nash, M.W.; Moss, F.M.; Mitchell, D.M.; Swallow, D.M. Genetic polymorphism of MUC7: Allele frequencies and association with asthma. Eur. J. Hum. Genet. 2001, 9, 347-354. [CrossRef]

47. Noguchi, E.; Shibasaki, M.; Kamioka, M.; Yokouchi, Y.; Yamakawa-Kobayashi, K.; Hamaguchi, H.; Matsui, A.; Arinami, T. New polymorphisms of haematopoietic prostaglandin D synthase and human prostanoid DP receptor genes. Clin. Exp. Allergy 2002, 32, 93-96. [CrossRef]

48. Noguchi, E.; Shibasaki, M.; Arinami, T.; Takeda, K.; Yokouchi, Y.; Kawashima, T.; Yanagi, H.; Matsui, A.; Hamaguchi, H. Association of asthma and the interleukin-4 promoter gene in Japanese. Clin. Exp. Allergy 1998, 28, 449-453. [CrossRef]

49. Noguchi, E.; Nukaga-Nishio, Y.; Jian, Z.; Yokouchi, Y.; Kamioka, M.; Yamakawa-Kobayashi, K.; Hamaguchi, H.; Matsui, A.; Shibasaki, M.; Arinami, T. Haplotypes of the 5' region of the IL-4 gene and SNPs in the intergene sequence between the IL-4 and IL-13 genes are associated with atopic asthma. Hum. Immunol. 2001, 62, 1251-1257. [CrossRef]

50. Howard, T.D.; Whittaker, P.A.; Zaiman, A.L.; Koppelman, G.H.; Xu, J.; Hanley, M.T.; Meyers, D.A.; Postma, D.S.; Bleecker, E.R. Identification and association of polymorphisms in the interleukin-13 gene with asthma and atopy in a Dutch population. Am. J. Respir. Cell Mol. Biol. 2001, 25, 377-384. [CrossRef]

51. Heinzmann, A.; Mao, X.Q.; Akaiwa, M.; Kreomer, R.T.; Gao, P.S.; Ohshima, K.; Umeshita, R.; Abe, Y.; Braun, S.; Yamashita, T.; et al. Genetic variants of IL-13 signalling and human asthma and atopy. Hum. Mol. Genet. 2000, 9, 549-559. [CrossRef] [PubMed]

52. van der Pouw Kraan, T.C.; van Veen, A.; Boeije, L.C.; van Tuyl, S.A.; de Groot, E.R.; Stapel, S.O.; Bakker, A.; Verweij, C.L.; Aarden, L.A.; van der Zee, J.S. An IL-13 promoter polymorphism associated with increased risk of allergic asthma. Genes Immun. 1999, 1, 61-65. [CrossRef] [PubMed]

53. Niimi, T.; Munakata, M.; Keck-Waggoner, C.L.; Popescu, N.C.; Levitt, R.C.; Hisada, M.; Kimura, S. A polymorphism in the human UGRP1 gene promoter that regulates transcription is associated with an increased risk of asthma. Am. J. Hum. Genet. 2002, 70, 718-725. [CrossRef] [PubMed]

54. Kotani, Y.; Nishimura, Y.; Maeda, H.; Yokoyama, M. Beta2-adrenergic receptor polymorphisms affect airway responsiveness to salbutamol in asthmatics. J. Asthma 1999, 36, 583-590. [CrossRef] [PubMed]

55. Reihsaus, E.; Innis, M.; MacIntyre, N.; Liggett, S.B. Mutations in the gene encoding for the beta 2-adrenergic receptor in normal and asthmatic subjects. Am. J. Respir. Cell Mol. Biol. 1993, 8, 334-339. [CrossRef]

56. Sanak, M.; Pierzchalska, M.; Bazan-Socha, S.; Szczeklik, A. Enhanced expression of the leukotriene C(4) synthase due to overactive transcription of an allelic variant associated with aspirin-intolerant asthma. Am. J. Respir. Cell Mol. Biol. 2000, 23, 290-296. [CrossRef]

57. Kawagishi, Y.; Mita, H.; Taniguchi, M.; Maruyama, M.; Oosaki, R.; Higashi, N.; Kashii, T.; Kobayashi, M.; Akiyama, K. Leukotriene C4 synthase promoter polymorphism in Japanese patients with aspirin-induced asthma. J. Allergy Clin. Immunol. 2002, 109, 936-942. [CrossRef]

58. Moffatt, M.F.; James, A.; Ryan, G.; Musk, A.W.; Cookson, W.O. Extended tumour necrosis factor/HLA-DR haplotypes and asthma in an Australian population sample. Thorax 1999, 54, 757-761. [CrossRef]

59. Kronqvist, M.; Johansson, E.; Pershagen, G.; Johansson, S.G.; van Hage-Hamsten, M. Increasing prevalence of asthma over 12 years among dairy farmers on Gotland, Sweden: Storage mites remain dominant allergens. Clin. Exp. Allergy 1999, $29,35-41$. [CrossRef]

60. Lara-Marquez, M.L.; Yunis, J.J.; Layrisse, Z.; Ortega, F.; Carvallo-Gil, E.; Montagnani, S.; Makhatadze, N.J.; Pocino, M.; Granja, C.; Yunis, E. Immunogenetics of atopic asthma: Association of DRB1*1101 DQA1*0501 DQB1*0301 haplotype with Dermatophagoides spp.-sensitive asthma in a sample of the Venezuelan population. Clin. Exp. Allergy 1999, 29, 60-71. [CrossRef]

61. Dekker, J.W.; Nizankowska, E.; Schmitz-Schumann, M.; Pile, K.; Bochenek, G.; Dyczek, A.; Cookson, W.O.; Szczeklik, A. Aspirin-induced asthma and HLA-DRB1 and HLA-DPB1 genotypes. Clin. Exp. Allergy 1997, 27, 574-577. [CrossRef]

62. Wilson, A.G.; Symons, J.A.; McDowell, T.L.; McDevitt, H.O.; Duff, G.W. Effects of a polymorphism in the human tumor necrosis factor alpha promoter on transcriptional activation. Proc. Natl. Acad. Sci. USA 1997, 94, 3195-3199. [CrossRef]

63. Chagani, T.; Pare, P.D.; Zhu, S.; Weir, T.D.; Bai, T.R.; Behbehani, N.A.; Fitzgerald, J.M.; Sandford, A.J. Prevalence of tumor necrosis factor-alpha and angiotensin converting enzyme polymorphisms in mild/moderate and fatal/near-fatal asthma. Am. J. Respir. Crit. Care Med. 1999, 160, 278-282. [CrossRef]

64. Witte, J.S.; Palmer, L.J.; O'Connor, R.D.; Hopkins, P.J.; Hall, J.M. Relation between tumour necrosis factor polymorphism TNFalpha-308 and risk of asthma. Eur. J. Hum. Genet. 2002, 10, 82-85. [CrossRef]

65. Noguchi, E.; Yokouchi, Y.; Shibasaki, M.; Inudou, M.; Nakahara, S.; Nogami, T.; Kamioka, M.; Yamakawa-Kobayashi, K.; Ichikawa, K.; Matsui, A.; et al. Association between TNFA polymorphism and the development of asthma in the Japanese population. Am. J. Respir. Crit. Care Med. 2002, 166, 43-46. [CrossRef]

66. Moffatt, M.F.; Cookson, W.O. Tumour necrosis factor haplotypes and asthma. Hum. Mol. Genet. 1997, 6, 551-554. [CrossRef]

67. Lin, Y.C.; Lu, C.C.; Su, H.J.; Shen, C.Y.; Lei, H.Y.; Guo, Y.L. The association between tumor necrosis factor, HLA-DR alleles, and IgE-mediated asthma in Taiwanese adolescents. Allergy 2002, 57, 831-834. [CrossRef]

68. Ismail, A.; Bousaffara, R.; Kaziz, J.; Zili, J.; el Kamel, A.; Tahar Sfar, M.; Remadi, S.; Chouchane, L. Polymorphism in transporter antigen peptides gene (TAP1) associated with atopy in Tunisians. J. Allergy Clin. Immunol. 1997, 99, 216-223. [CrossRef]

69. Hang, L.W.; Hsia, T.C.; Chen, W.C.; Chen, H.Y.; Tsai, F.J. TAP1 gene Accl polymorphism is associated with atopic bronchial asthma. J. Clin. Lab. Anal. 2003, 17, 57-60. [CrossRef] 
70. Stafforini, D.M.; Numao, T.; Tsodikov, A.; Vaitkus, D.; Fukuda, T.; Watanabe, N.; Fueki, N.; McIntyre, T.M.; Zimmerman, G.A.; Makino, S.; et al. Deficiency of platelet-activating factor acetylhydrolase is a severity factor for asthma. J. Clin. Investig. 1999, 103, 989-997. [CrossRef]

71. Kruse, S.; Mao, X.Q.; Heinzmann, A.; Blattmann, S.; Roberts, M.H.; Braun, S.; Gao, P.S.; Forster, J.; Kuehr, J.; Hopkin, J.M.; et al. The Ile198Thr and Ala379Val variants of plasmatic PAF-acetylhydrolase impair catalytical activities and are associated with atopy and asthma. Am. J. Hum. Genet. 2000, 66, 1522-1530. [CrossRef]

72. Ito, S.; Noguchi, E.; Shibasaki, M.; Yamakawa-Kobayashi, K.; Watanabe, H.; Arinami, T. Evidence for an association between plasma platelet-activating factor acetylhydrolase deficiency and increased risk of childhood atopic asthma. J. Hum. Genet. 2002, 47, 99-101. [CrossRef]

73. Immervoll, T.; Loesgen, S.; Dutsch, G.; Gohlke, H.; Herbon, N.; Klugbauer, S.; Dempfle, A.; Bickeboller, H.; Becker-Follmann, J.; Ruschendorf, F; et al. Fine mapping and single nucleotide polymorphism association results of candidate genes for asthma and related phenotypes. Hum. Mutat. 2001, 18, 327-336. [CrossRef]

74. Shin, H.D.; Kim, L.H.; Park, B.L.; Jung, J.H.; Kim, J.Y.; Chung, I.Y.; Kim, J.S.; Lee, J.H.; Chung, S.H.; Kim, Y.H.; et al. Association of Eotaxin gene family with asthma and serum total IgE. Hum. Mol. Genet. 2003, 12, 1279-1285. [CrossRef]

75. Schroeder, S.A.; Gaughan, D.M.; Swift, M. Protection against bronchial asthma by CFTR delta F508 mutation: A heterozygote advantage in cystic fibrosis. Nat. Med. 1995, 1, 703-705. [CrossRef]

76. Dahl, M.; Tybærg-Hansen, A.; Lange, P.; Nordestgaard, B.G. $\Delta$ F508 heterozygosity in cystic fibrosis and susceptibility to asthma. Lancet 1998, 351, 1911-1913. [CrossRef]

77. Lazaro, C.; de Cid, R.; Sunyer, J.; Soriano, J.; Gimenez, J.; Alvarez, M.; Casals, T.; Anto, J.M.; Estivill, X. Missense mutations in the cystic fibrosis gene in adult patients with asthma. Hum. Mutat. 1999, 14, 510-519. [CrossRef]

78. Tzetis, M.; Efthymiadou, A.; Strofalis, S.; Psychou, P.; Dimakou, A.; Pouliou, E.; Doudounakis, S.; Kanavakis, E. CFTR gene mutations-including three novel nucleotide substitutions-And haplotype background in patients with asthma, disseminated bronchiectasis and chronic obstructive pulmonary disease. Hum. Genet. 2001, 108, 216-221. [CrossRef]

79. Lee, Y.C.; Cheon, K.T.; Lee, H.B.; Kim, W.; Rhee, Y.K.; Kim, D.S. Gene polymorphisms of endothelial nitric oxide synthase and angiotensin-converting enzyme in patients with asthma. Allergy 2000, 55, 959-963. [CrossRef]

80. Laing, I.A.; Goldblatt, J.; Eber, E.; Hayden, C.M.; Rye, P.J.; Gibson, N.A.; Palmer, L.J.; Burton, P.R.; Le Souef, P.N. A polymorphism of the CC16 gene is associated with an increased risk of asthma. J. Med. Genet. 1998, 35, 463-467. [CrossRef] [PubMed]

81. Laing, I.A.; Hermans, C.; Bernard, A.; Burton, P.R.; Goldblatt, J.; Le Souef, P.N. Association between plasma CC16 levels, the A38G polymorphism, and asthma. Am. J. Respir. Crit. Care Med. 2000, 161, 124-127. [CrossRef] [PubMed]

82. Choi, M.; Zhang, Z.; Ten Kate, L.P.; Collee, J.M.; Gerritsen, J.; Mukherjee, A.B. Human uteroglobin gene polymorphisms and genetic susceptibility to asthma. Ann. N. Y. Acad. Sci. 2000, 923, 303-306. [CrossRef] [PubMed]

83. Green, S.L.; Gaillard, M.C.; Song, E.; Dewar, J.B.; Halkas, A. Polymorphisms of the beta chain of the high-affinity immunoglobulin E receptor (Fcepsilon RI-beta) in South African black and white asthmatic and nonasthmatic individuals. Am. J. Respir. Crit. Care Med. 1998, 158, 1487-1492. [CrossRef] [PubMed]

84. Hijazi, Z.; Haider, M.Z.; Khan, M.R.; Al-Dowaisan, A.A. High frequency of IgE receptor Fc epsilonRIbeta variant (Leu181/Leu183) in Kuwaiti Arabs and its association with asthma. Clin. Genet. 1998, 53, 149-152. [CrossRef]

85. Palmer, L.J.; Rye, P.J.; Gibson, N.A.; Moffatt, M.F.; Goldblatt, J.; Burton, P.R.; Cookson, W.O.; Lesouef, P.N. Association of FcepsilonR1-beta polymorphisms with asthma and associated traits in Australian asthmatic families. Clin. Exp. Allergy 1999, 29, 1555-1562. [CrossRef]

86. Cox, H.E.; Moffatt, M.F.; Faux, J.A.; Walley, A.J.; Coleman, R.; Trembath, R.C.; Cookson, W.O.; Harper, J.I. Association of atopic dermatitis to the beta subunit of the high affinity immunoglobulin E receptor. Br. J. Dermatol. 1998, 138, 182-187. [CrossRef]

87. van Hage-Hamsten, M.; Johansson, E.; Kronqvist, M.; Loughry, A.; Cookson, W.O.; Moffatt, M.F. Associations of Fc epsilon R1-beta polymorphisms with immunoglobin E antibody responses to common inhalant allergens in a rural population. Clin. Exp. Allergy 2002, 32, 838-842. [CrossRef]

88. Hizawa, N.; Yamaguchi, E.; Jinushi, E.; Kawakami, Y. A common FCER1B gene promoter polymorphism influences total serum IgE levels in a Japanese population. Am. J. Respir. Crit. Care Med. 2000, 161, 906-909. [CrossRef]

89. Shirakawa, T.; Mao, X.Q.; Sasaki, S.; Enomoto, T.; Kawai, M.; Morimoto, K.; Hopkin, J. Association between atopic asthma and a coding variant of Fc epsilon RI beta in a Japanese population. Hum. Mol. Genet. 1996, 5, 1129-1130. [CrossRef]

90. Fryer, A.A.; Bianco, A.; Hepple, M.; Jones, P.W.; Strange, R.C.; Spiteri, M.A. Polymorphism at the glutathione S-transferase GSTP1 locus. A new marker for bronchial hyperresponsiveness and asthma. Am. J. Respir. Crit. Care Med. 2000, 161, 1437-1442. [CrossRef]

91. Noguchi, E.; Shibasaki, M.; Inudou, M.; Kamioka, M.; Yokouchi, Y.; Yamakawa-Kobayashi, K.; Hamaguchi, H.; Matsui, A.; Arinami, T. Association between a new polymorphism in the activation-induced cytidine deaminase gene and atopic asthma and the regulation of total serum IgE levels. J. Allergy Clin. Immunol. 2001, 108, 382-386. [CrossRef]

92. Tamura, K.; Arakawa, H.; Suzuki, M.; Kobayashi, Y.; Mochizuki, H.; Kato, M.; Tokuyama, K.; Morikawa, A. Novel dinucleotide repeat polymorphism in the first exon of the STAT-6 gene is associated with allergic diseases. Clin. Exp. Allergy 2001, 31, 1509-1514. [CrossRef] 
93. Grasemann, H.; Yandava, C.N.; Storm van's Gravesande, K.; Deykin, A.; Pillari, A.; Ma, J.; Sonna, L.A.; Lilly, C.; Stampfer, M.J.; Israel, E.; et al. A neuronal NO synthase (NOS1) gene polymorphism is associated with asthma. Biochem. Biophys. Res. Commun. 2000, 272, 391-394. [CrossRef]

94. Gao, P.S.; Kawada, H.; Kasamatsu, T.; Mao, X.Q.; Roberts, M.H.; Miyamoto, Y.; Yoshimura, M.; Saitoh, Y.; Yasue, H.; Nakao, K.; et al. Variants of NOS1, NOS2, and NOS3 genes in asthmatics. Biochem. Biophys. Res. Commun. 2000, 267, 761-763. [CrossRef]

95. Malerba, G.; Patuzzo, C.; Trabetti, E.; Lauciello, M.C.; Galavotti, R.; Pescollderungg, L.; Whalen, M.B.; Zanoni, G.; Martinati, L.C.; Boner, A.L.; et al. Chromosome 14 linkage analysis and mutation study of 2 serpin genes in allergic asthmatic families. J. Allergy Clin. Immunol. 2001, 107, 654-658. [CrossRef]

96. Howard, T.D.; Koppelman, G.H.; Xu, J.; Zheng, S.L.; Postma, D.S.; Meyers, D.A.; Bleecker, E.R. Gene-gene interaction in asthma: IL4RA and IL13 in a Dutch population with asthma. Am. J. Hum. Genet. 2002, 70, 230-236. [CrossRef]

97. Ober, C.; Leavitt, S.A.; Tsalenko, A.; Howard, T.D.; Hoki, D.M.; Daniel, R.; Newman, D.L.; Wu, X.; Parry, R.; Lester, L.A.; et al. Variation in the interleukin 4-receptor alpha gene confers susceptibility to asthma and atopy in ethnically diverse populations. Am. J. Hum. Genet. 2000, 66, 517-526. [CrossRef]

98. Rosa-Rosa, L.; Zimmermann, N.; Bernstein, J.A.; Rothenberg, M.E.; Khurana Hershey, G.K. The R576 IL-4 receptor alpha allele correlates with asthma severity. J. Allergy Clin. Immunol. 1999, 104, 1008-1014. [CrossRef]

99. Risma, K.A.; Wang, N.; Andrews, R.P.; Cunningham, C.M.; Ericksen, M.B.; Bernstein, J.A.; Chakraborty, R.; Hershey, G.K. V75R576 IL-4 receptor alpha is associated with allergic asthma and enhanced IL-4 receptor function. J. Immunol. 2002, 169, 1604-1610. [CrossRef]

100. Mitsuyasu, H.; Izuhara, K.; Mao, X.Q.; Gao, P.S.; Arinobu, Y.; Enomoto, T.; Kawai, M.; Sasaki, S.; Dake, Y.; Hamasaki, N.; et al. Ile50Val variant of IL4R alpha upregulates IgE synthesis and associates with atopic asthma. Nat. Genet. 1998, 19, 119-120. [CrossRef]

101. Hizawa, N.; Yamaguchi, E.; Konno, S.; Tanino, Y.; Jinushi, E.; Nishimura, M. A functional polymorphism in the RANTES gene promoter is associated with the development of late-onset asthma. Am. J. Respir. Crit. Care Med. 2002, 166, 686-690. [CrossRef]

102. Fryer, A.A.; Spiteri, M.A.; Bianco, A.; Hepple, M.; Jones, P.W.; Strange, R.C.; Makki, R.; Tavernier, G.; Smilie, F.I.; Custovic, A.; et al. The -403 G->A promoter polymorphism in the RANTES gene is associated with atopy and asthma. Genes Immun. 2000, 1, 509-514. [CrossRef]

103. Benessiano, J.; Crestani, B.; Mestari, F.; Klouche, W.; Neukirch, F.; Hacein-Bey, S.; Durand, G.; Aubier, M. High frequency of a deletion polymorphism of the angiotensin-converting enzyme gene in asthma. J. Allergy Clin. Immunol. 1997, 99, 53-57. [CrossRef]

104. Holla, L.; Vasku, A.; Znojil, V.; Siskova, L.; Vacha, J. Association of 3 gene polymorphisms with atopic diseases. J. Allergy Clin. Immunol. 1999, 103, 702-708. [CrossRef]

105. Unoki, M.; Furuta, S.; Onouchi, Y.; Watanabe, O.; Doi, S.; Fujiwara, H.; Miyatake, A.; Fujita, K.; Tamari, M.; Nakamura, Y. Association studies of 33 single nucleotide polymorphisms (SNPs) in 29 candidate genes for bronchial asthma: Positive association a T924C polymorphism in the thromboxane A2 receptor gene. Hum. Genet. 2000, 106, 440-446. [CrossRef]

106. Lee, S.Y.; Lee, Y.H.; Shin, C.; Shim, J.J.; Kang, K.H.; Yoo, S.H.; In, K.H. Association of asthma severity and bronchial hyperresponsiveness with a polymorphism in the cytotoxic T-lymphocyte antigen-4 gene. Chest 2002, 122, 171-176. [CrossRef]

107. Sandford, A.J.; Chagani, T.; Zhu, S.; Weir, T.D.; Bai, T.R.; Spinelli, J.J.; Fitzgerald, J.M.; Behbehani, N.A.; Tan, W.C.; Pare, P.D. Polymorphisms in the IL4, IL4RA, and FCERIB genes and asthma severity. J. Allergy Clin. Immunol. 2000, 106, 135-140. [CrossRef]

108. Holloway, J.W.; Dunbar, P.R.; Riley, G.A.; Sawyer, G.M.; Fitzharris, P.F.; Pearce, N.; Le Gros, G.S.; Beasley, R. Association of beta2-adrenergic receptor polymorphisms with severe asthma. Clin. Exp. Allergy 2000, 30, 1097-1103. [CrossRef]

109. Pulleyn, L.J.; Newton, R.; Adcock, I.M.; Barnes, P.J. TGFbeta1 allele association with asthma severity. Hum. Genet. 2001, 109, 623-627. [CrossRef]

110. Duetsch, G.; Illig, T.; Loesgen, S.; Rohde, K.; Klopp, N.; Herbon, N.; Gohlke, H.; Altmueller, J.; Wjst, M. STAT6 as an asthma candidate gene: Polymorphism-screening, association and haplotype analysis in a Caucasian sib-pair study. Hum. Mol. Genet. 2002, 11, 613-621. [CrossRef]

111. Nakamura, H.; Luster, A.D.; Nakamura, T.; In, K.H.; Sonna, L.A.; Deykin, A.; Israel, E.; Drazen, J.M.; Lilly, C.M. Variant eotaxin: Its effects on the asthma phenotype. J. Allergy Clin. Immunol. 2001, 108, 946-953. [CrossRef] [PubMed]

112. Rosenwasser, L.J.; Klemm, D.J.; Dresback, J.K.; Inamura, H.; Mascali, J.J.; Klinnert, M.; Borish, L. Promoter polymorphisms in the chromosome 5 gene cluster in asthma and atopy. Clin. Exp. Allergy 1995, 25 (Suppl. 2), 74-78, discussion 95-76. [CrossRef] [PubMed]

113. Baldini, M.; Lohman, I.C.; Halonen, M.; Erickson, R.P.; Holt, P.G.; Martinez, F.D. A Polymorphism* in the $5^{\prime}$ flanking region of the CD14 gene is associated with circulating soluble CD14 levels and with total serum immunoglobulin E. Am. J. Respir. Cell Mol. Biol. 1999, 20, 976-983. [CrossRef] [PubMed]

114. Koppelman, G.H.; Reijmerink, N.E.; Colin Stine, O.; Howard, T.D.; Whittaker, P.A.; Meyers, D.A.; Postma, D.S.; Bleecker, E.R. Association of a promoter polymorphism of the CD14 gene and atopy. Am. J. Respir. Crit. Care Med. 2001, 163, 965-969. [CrossRef] [PubMed]

115. Moffatt, M.F.; Schou, C.; Faux, J.A.; Abecasis, G.R.; James, A.; Musk, A.W.; Cookson, W.O. Association between quantitative traits underlying asthma and the HLA-DRB1 locus in a family-based population sample. Eur. J. Hum. Genet. 2001, 9, 341-346. [CrossRef] [PubMed] 
116. Moffatt, M.F.; Faux, J.A.; Lester, S.; Pare, P.; McCluskey, J.; Spargo, R.; James, A.; Musk, A.W.; Cookson, W.O. Atopy, respiratory function and HLA-DR in Aboriginal Australians. Hum. Mol. Genet. 2003, 12, 625-630. [CrossRef] [PubMed]

117. Spielman, R.S.; Ewens, W.J. The TDT and other family-based tests for linkage disequilibrium and association. Am. J. Hum. Genet. 1996, 59, 983-989.

118. Gao, P.S.; Mao, X.Q.; Jouanguy, E.; Pallier, A.; Doffinger, R.; Tanaka, Y.; Nakashima, H.; Otsuka, T.; Roberts, M.H.; Enomoto, T.; et al. Nonpathogenic common variants of IFNGR1 and IFNGR2 in association with total serum IgE levels. Biochem. Biophys. Res. Commun. 1999, 263, 425-429. [CrossRef]

119. Nagarkatti, R.; Rao, C.B.; Rishi, J.P.; Chetiwal, R.; Shandilya, V.; Vijayan, V.; Kumar, R.; Pemde, H.K.; Sharma, S.K.; Sharma, S.; et al. Association of IFNG gene polymorphism with asthma in the Indian population. J. Allergy Clin. Immunol. 2002, 110, 410-412 [CrossRef]

120. Kauppi, P.; Lindblad-Toh, K.; Sevon, P.; Toivonen, H.T.; Rioux, J.D.; Villapakkam, A.; Laitinen, L.A.; Hudson, T.J.; Kere, J.; Laitinen, T. A second-generation association study of the $5 \mathrm{q} 31$ cytokine gene cluster and the interleukin-4 receptor in asthma. Genomics 2001, 77, 35-42. [CrossRef]

121. Bottini, N.; Borgiani, P.; Otsu, A.; Saccucci, P.; Stefanini, L.; Greco, E.; Fontana, L.; Hopkin, J.M.; Mao, X.Q.; Shirakawa, T. IL-4 receptor alpha chain genetic polymorphism and total IgE levels in the English population: Two-locus haplotypes are more informative than individual SNPs. Clin. Genet. 2002, 61, 288-292. [CrossRef]

122. Hobbs, K.; Negri, J.; Klinnert, M.; Rosenwasser, L.J.; Borish, L. Interleukin-10 and transforming growth factor-beta promoter polymorphisms in allergies and asthma. Am. J. Respir. Crit. Care Med. 1998, 158, 1958-1962. [CrossRef]

123. Karjalainen, J.; Hulkkonen, J.; Nieminen, M.M.; Huhtala, H.; Aromaa, A.; Klaukka, T.; Hurme, M. Interleukin-10 gene promoter region polymorphism is associated with eosinophil count and circulating immunoglobulin E in adult asthma. Clin. Exp. Allergy 2003, 33, 78-83. [CrossRef]

124. Hizawa, N.; Yamaguchi, E.; Jinushi, E.; Konno, S.; Kawakami, Y.; Nishimura, M. Increased total serum IgE levels in patients with asthma and promoter polymorphisms at CTLA4 and FCER1B. J. Allergy Clin. Immunol. 2001, 108, 74-79. [CrossRef]

125. Suzuki, I.; Hizawa, N.; Yamaguchi, E.; Kawakami, Y. Association between a C+33T polymorphism in the IL-4 promoter region and total serum IgE levels. Clin. Exp. Allergy 2000, 30, 1746-1749. [CrossRef]

126. Holla, L.I.; Buckova, D.; Kuhrova, V.; Stejskalova, A.; Francova, H.; Znojil, V.; Vacha, J. Prevalence of endothelial nitric oxide synthase gene polymorphisms in patients with atopic asthma. Clin. Exp. Allergy 2002, 32, 1193-1198. [CrossRef]

127. Walley, A.J.; Cookson, W.O. Investigation of an interleukin-4 promoter polymorphism for associations with asthma and atopy. J. Med. Genet. 1996, 33, 689-692. [CrossRef]

128. Stephan, V.; Kuehr, J.; Seibt, A.; Saueressig, H.; Zingsem, S.; Dinh, T.D.; Moseler, M.; Wahn, V.; Deichmann, K.A. Genetic linkage of HLA-class II locus to mite-specific IgE immune responsiveness. Clin. Exp. Allergy 1999, 29, 1049-1054. [CrossRef]

129. Hu, C.; Hsu, P.N.; Lin, R.H.; Hsieh, K.H.; Chua, K.Y. HLA DPB1*0201 allele is negatively associated with immunoglobulin E responsiveness specific for house dust mite allergens in Taiwan. Clin. Exp. Allergy 2000, 30, 538-545. [CrossRef]

130. Hill, M.R.; Cookson, W.O. A new variant of the beta subunit of the high-affinity receptor for immunoglobulin $\mathrm{E}$ (Fc epsilon RI-beta E237G): Associations with measures of atopy and bronchial hyper-responsiveness. Hum. Mol. Genet. 1996, 5, 959-962. [CrossRef]

131. D'Amato, M.; Vitiani, L.R.; Petrelli, G.; Ferrigno, L.; di Pietro, A.; Trezza, R.; Matricardi, P.M. Association of persistent bronchial hyperresponsiveness with beta2-adrenoceptor (ADRB2) haplotypes. A population study. Am. J. Respir. Crit. Care Med. 1998, 158, 1968-1973. [CrossRef]

132. Ulbrecht, M.; Hergeth, M.T.; Wjst, M.; Heinrich, J.; Bickeboller, H.; Wichmann, H.E.; Weiss, E.H. Association of beta(2)adrenoreceptor variants with bronchial hyperresponsiveness. Am. J. Respir. Crit. Care Med. 2000, 161, 469-474. [CrossRef]

133. Li Kam Wa, T.C.; Mansur, A.H.; Britton, J.; Williams, G.; Pavord, I.; Richards, K.; Campbell, D.A.; Morton, N.; Holgate, S.T.; Morrison, J.F. Association between-308 tumour necrosis factor promoter polymorphism and bronchial hyperreactivity in asthma. Clin. Exp. Allergy 1999, 29, 1204-1208. [CrossRef]

134. Burchard, E.G.; Silverman, E.K.; Rosenwasser, L.J.; Borish, L.; Yandava, C.; Pillari, A.; Weiss, S.T.; Hasday, J.; Lilly, C.M.; Ford, J.G.; et al. Association between a sequence variant in the IL-4 gene promoter and FEV(1) in asthma. Am. J. Respir. Crit. Care Med. 1999, 160, 919-922. [CrossRef]

135. Summerhill, E.; Leavitt, S.A.; Gidley, H.; Parry, R.; Solway, J.; Ober, C. beta(2)-adrenergic receptor Arg16/Arg16 genotype is associated with reduced lung function, but not with asthma, in the Hutterites. Am. J. Respir. Crit. Care Med. 2000, 162, 599-602. [CrossRef] [PubMed]

136. Sayers, I.; Barton, S.; Rorke, S.; Beghe, B.; Hayward, B.; Van Eerdewegh, P.; Keith, T.; Clough, J.B.; Ye, S.; Holloway, J.W.; et al. Allelic association and functional studies of promoter polymorphism in the leukotriene C4 synthase gene (LTC4S) in asthma. Thorax 2003, 58, 417-424. [CrossRef] [PubMed]

137. Pickrell, J.K.; Berisa, T.; Liu, J.Z.; Segurel, L.; Tung, J.Y.; Hinds, D.A. Detection and interpretation of shared genetic influences on 42 human traits. Nat. Genet. 2016, 48, 709-717. [CrossRef] [PubMed]

138. Ferreira, M.A.; Matheson, M.C.; Duffy, D.L.; Marks, G.B.; Hui, J.; Le Souef, P.; Danoy, P.; Baltic, S.; Nyholt, D.R.; Jenkins, M.; et al. Identification of IL6R and chromosome 11q13.5 as risk loci for asthma. Lancet 2011, 378, 1006-1014. [CrossRef]

139. Yan, Q.; Brehm, J.; Pino-Yanes, M.; Forno, E.; Lin, J.; Oh, S.S.; Acosta-Perez, E.; Laurie, C.C.; Cloutier, M.M.; Raby, B.A.; et al. A meta-analysis of genome-wide association studies of asthma in Puerto Ricans. Eur. Respir. J. 2017, 49. [CrossRef] 
140. Mathias, R.A.; Grant, A.V.; Rafaels, N.; Hand, T.; Gao, L.; Vergara, C.; Tsai, Y.J.; Yang, M.; Campbell, M.; Foster, C.; et al. A genome-wide association study on African-ancestry populations for asthma. J. Allergy Clin. Immunol. 2010, 125, 336-346.e4. [CrossRef]

141. Hirota, T.; Takahashi, A.; Kubo, M.; Tsunoda, T.; Tomita, K.; Doi, S.; Fujita, K.; Miyatake, A.; Enomoto, T.; Miyagawa, T.; et al. Genome-wide association study identifies three new susceptibility loci for adult asthma in the Japanese population. Nat. Genet. 2011, 43, 893-896. [CrossRef]

142. Himes, B.E.; Hunninghake, G.M.; Baurley, J.W.; Rafaels, N.M.; Sleiman, P.; Strachan, D.P.; Wilk, J.B.; Willis-Owen, S.A.; Klanderman, B.; Lasky-Su, J.; et al. Genome-wide association analysis identifies PDE4D as an asthma-susceptibility gene. Am. J. Hum. Genet. 2009, 84, 581-593. [CrossRef]

143. Almoguera, B.; Vazquez, L.; Mentch, F.; Connolly, J.; Pacheco, J.A.; Sundaresan, A.S.; Peissig, P.L.; Linneman, J.G.; McCarty, C.A.; Crosslin, D.; et al. Identification of Four Novel Loci in Asthma in European American and African American Populations. Am. J. Respir. Crit. Care Med. 2017, 195, 456-463. [CrossRef]

144. Li, X.; Howard, T.D.; Zheng, S.L.; Haselkorn, T.; Peters, S.P.; Meyers, D.A.; Bleecker, E.R. Genome-wide association study of asthma identifies RAD50-IL13 and HLA-DR/DQ regions. J. Allergy Clin. Immunol. 2010, 125, 328-335.e311. [CrossRef]

145. Noguchi, E.; Sakamoto, H.; Hirota, T.; Ochiai, K.; Imoto, Y.; Sakashita, M.; Kurosaka, F.; Akasawa, A.; Yoshihara, S.; Kanno, N.; et al. Genome-wide association study identifies HLA-DP as a susceptibility gene for pediatric asthma in Asian populations. PLoS Genet. 2011, 7, e1002170. [CrossRef]

146. Lasky-Su, J.; Himes, B.E.; Raby, B.A.; Klanderman, B.J.; Sylvia, J.S.; Lange, C.; Melen, E.; Martinez, F.D.; Israel, E.; Gauderman, J.; et al. HLA-DQ strikes again: Genome-wide association study further confirms HLA-DQ in the diagnosis of asthma among adults. Clin. Exp. Allergy 2012, 42, 1724-1733. [CrossRef]

147. Lowe, R.; Shirley, N.; Bleackley, M.; Dolan, S.; Shafee, T. Transcriptomics technologies. PLoS Comput. Biol. 2017, 13 , e1005457. [CrossRef]

148. Liew, C.C.; Ma, J.; Tang, H.C.; Zheng, R.; Dempsey, A.A. The peripheral blood transcriptome dynamically reflects system wide biology: A potential diagnostic tool. J. Lab. Clin. Med. 2006, 147, 126-132. [CrossRef]

149. Bjornsdottir, U.S.; Holgate, S.T.; Reddy, P.S.; Hill, A.A.; McKee, C.M.; Csimma, C.I.; Weaver, A.A.; Legault, H.M.; Small, C.G.; Ramsey, R.C.; et al. Pathways activated during human asthma exacerbation as revealed by gene expression patterns in blood. PLoS ONE 2011, 6, e21902. [CrossRef]

150. Bigler, J.; Boedigheimer, M.; Schofield, J.P.R.; Skipp, P.J.; Corfield, J.; Rowe, A.; Sousa, A.R.; Timour, M.; Twehues, L.; Hu, X.; et al. A Severe Asthma Disease Signature from Gene Expression Profiling of Peripheral Blood from U-BIOPRED Cohorts. Am. J. Respir. Crit. Care Med. 2017, 195, 1311-1320. [CrossRef]

151. Woodruff, P.G.; Boushey, H.A.; Dolganov, G.M.; Barker, C.S.; Yang, Y.H.; Donnelly, S.; Ellwanger, A.; Sidhu, S.S.; Dao-Pick, T.P.; Pantoja, C.; et al. Genome-wide profiling identifies epithelial cell genes associated with asthma and with treatment response to corticosteroids. Proc. Natl. Acad. Sci. USA 2007, 104, 15858-15863. [CrossRef] [PubMed]

152. Woodruff, P.G.; Modrek, B.; Choy, D.F.; Jia, G.; Abbas, A.R.; Ellwanger, A.; Koth, L.L.; Arron, J.R.; Fahy, J.V. T-helper type 2-driven inflammation defines major subphenotypes of asthma. Am. J. Respir. Crit. Care Med. 2009, 180, 388-395. [CrossRef] [PubMed]

153. Wilson, S.J.; Ward, J.A.; Sousa, A.R.; Corfield, J.; Bansal, A.T.; De Meulder, B.; Lefaudeux, D.; Auffray, C.; Loza, M.J.; Baribaud, F.; et al. Severe asthma exists despite suppressed tissue inflammation: Findings of the U-BIOPRED study. Eur. Respir. J. 2016, 48, 1307-1319. [CrossRef] [PubMed]

154. Modena, B.D.; Bleecker, E.R.; Busse, W.W.; Erzurum, S.C.; Gaston, B.M.; Jarjour, N.N.; Meyers, D.A.; Milosevic, J.; Tedrow, J.R.; Wu, W.; et al. Gene Expression Correlated with Severe Asthma Characteristics Reveals Heterogeneous Mechanisms of Severe Disease. Am. J. Respir. Crit. Care Med. 2017, 195, 1449-1463. [CrossRef] [PubMed]

155. Baines, K.J.; Simpson, J.L.; Wood, L.G.; Scott, R.J.; Gibson, P.G. Transcriptional phenotypes of asthma defined by gene expression profiling of induced sputum samples. J. Allergy Clin. Immunol. 2011, 127, 153-160.e9. [CrossRef]

156. Peters, M.C.; Mekonnen, Z.K.; Yuan, S.; Bhakta, N.R.; Woodruff, P.G.; Fahy, J.V. Measures of gene expression in sputum cells can identify TH2-high and TH2-low subtypes of asthma. J. Allergy Clin. Immunol. 2014, 133, 388-394. [CrossRef]

157. Baines, K.J.; Simpson, J.L.; Wood, L.G.; Scott, R.J.; Fibbens, N.L.; Powell, H.; Cowan, D.C.; Taylor, D.R.; Cowan, J.O.; Gibson, P.G. Sputum gene expression signature of 6 biomarkers discriminates asthma inflammatory phenotypes. J. Allergy Clin. Immunol. 2014, 133, 997-1007. [CrossRef]

158. Peters, M.C.; Ringel, L.; Dyjack, N.; Herrin, R.; Woodruff, P.G.; Rios, C.; O'Connor, B.; Fahy, J.V.; Seibold, M.A. A Transcriptomic Method to Determine Airway Immune Dysfunction in T2-High and T2-Low Asthma. Am. J. Respir. Crit. Care Med. 2019, 199, 465-477. [CrossRef]

159. Kim, B.K.; Lee, H.S.; Sohn, K.H.; Lee, S.Y.; Cho, S.H.; Park, H.W. Different Biological Pathways Are Up-regulated in the Elderly With Asthma: Sputum Transcriptomic Analysis. Allergy Asthma Immunol. Res. 2019, 11, 104-115. [CrossRef]

160. Pandey, G.; Pandey, O.P.; Rogers, A.J.; Ahsen, M.E.; Hoffman, G.E.; Raby, B.A.; Weiss, S.T.; Schadt, E.E.; Bunyavanich, S. A Nasal Brush-based Classifier of Asthma Identified by Machine Learning Analysis of Nasal RNA Sequence Data. Sci. Rep. $2018,8,8826$. [CrossRef]

161. Weathington, N.; O’Brien, M.E.; Radder, J.; Whisenant, T.C.; Bleecker, E.R.; Busse, W.W.; Erzurum, S.C.; Gaston, B.; Hastie, A.T.; Jarjour, N.N.; et al. BAL Cell Gene Expression in Severe Asthma Reveals Mechanisms of Severe Disease and Influences of Medications. Am. J. Respir. Crit. Care Med. 2019, 200, 837-856. [CrossRef] 
162. Hekking, P.P.; Loza, M.J.; Pavlidis, S.; de Meulder, B.; Lefaudeux, D.; Baribaud, F.; Auffray, C.; Wagener, A.H.; Brinkman, P.I.; Lutter, R.I.; et al. Pathway discovery using transcriptomic profiles in adult-onset severe asthma. J. Allergy Clin. Immunol. 2018, 141, 1280-1290. [CrossRef]

163. Aslam, B.; Basit, M.; Nisar, M.A.; Khurshid, M.; Rasool, M.H. Proteomics: Technologies and Their Applications. J. Chromatogr. Sci. 2017, 55, 182-196. [CrossRef]

164. Barbosa, E.B.; Vidotto, A.; Polachini, G.M.; Henrique, T.; Marqui, A.B.; Tajara, E.H. Proteomics: Methodologies and applications to the study of human diseases. Rev. Assoc. Med. Bras. 2012, 58, 366-375.

165. Lee, S.H.; Rhim, T.; Choi, Y.S.; Min, J.W.; Kim, S.H.; Cho, S.Y.; Paik, Y.K.; Park, C.S. Complement C3a and C4a increased in plasma of patients with aspirin-induced asthma. Am. J. Respir. Crit. Care Med. 2006, 173, 370-378. [CrossRef]

166. Gharib, S.A.; Nguyen, E.V.; Lai, Y.; Plampin, J.D.; Goodlett, D.R.; Hallstrand, T.S. Induced sputum proteome in healthy subjects and asthmatic patients. J. Allergy Clin. Immunol. 2011, 128, 1176-1184.e1176. [CrossRef]

167. Lee, T.H.; Jang, A.S.; Park, J.S.; Kim, T.H.; Choi, Y.S.; Shin, H.R.; Park, S.W.; Uh, S.T.; Choi, J.S.; Kim, Y.H.; et al. Elevation of S100 calcium binding protein A9 in sputum of neutrophilic inflammation in severe uncontrolled asthma. Ann. Allergy Asthma Immunol. 2013, 111, 268-275.e1. [CrossRef]

168. Wu, J.; Kobayashi, M.; Sousa, E.A.; Liu, W.; Cai, J.; Goldman, S.J.; Dorner, A.J.; Projan, S.J.; Kavuru, M.S.; Qiu, Y.; et al. Differential proteomic analysis of bronchoalveolar lavage fluid in asthmatics following segmental antigen challenge. Mol. Cell Proteomics 2005, 4, 1251-1264. [CrossRef]

169. Candiano, G.; Bruschi, M.; Pedemonte, N.; Caci, E.; Liberatori, S.; Bini, L.; Pellegrini, C.; Vigano, M.; O'Connor, B.J.; Lee, T.H.; et al. Gelsolin secretion in interleukin-4-treated bronchial epithelia and in asthmatic airways. Am. J. Respir. Crit. Care Med. 2005, 172, 1090-1096. [CrossRef]

170. Ghosh, S.; Janocha, A.J.; Aronica, M.A.; Swaidani, S.; Comhair, S.A.; Xu, W.; Zheng, L.; Kaveti, S.; Kinter, M.; Hazen, S.L.; et al. Nitrotyrosine proteome survey in asthma identifies oxidative mechanism of catalase inactivation. J. Immunol. 2006, 176, 5587-5597. [CrossRef]

171. Cederfur, C.; Malmstrom, J.; Nihlberg, K.; Block, M.; Breimer, M.E.; Bjermer, L.; Westergren-Thorsson, G.; Leffler, H. Glycoproteomic identification of galectin-3 and -8 ligands in bronchoalveolar lavage of mild asthmatics and healthy subjects. Biochim. Biophys. Acta 2012, 1820, 1429-1436. [CrossRef]

172. O'Neil, S.E.; Sitkauskiene, B.; Babusyte, A.; Krisiukeniene, A.; Stravinskaite-Bieksiene, K.; Sakalauskas, R.; Sihlbom, C.; Ekerljung, L.; Carlsohn, E.; Lotvall, J. Network analysis of quantitative proteomics on asthmatic bronchi: Effects of inhaled glucocorticoid treatment. Respir. Res. 2011, 12, 124. [CrossRef]

173. Dunn, W.B.; Bailey, N.J.; Johnson, H.E. Measuring the metabolome: Current analytical technologies. Analyst 2005, 130, 606-625. [CrossRef]

174. Lei, Z.; Huhman, D.V.; Sumner, L.W. Mass spectrometry strategies in metabolomics. J. Biol. Chem. 2011, 286, $25435-25442$. [CrossRef]

175. Sahoo, N.; Tejaswini, G.; Sahu, M.; Muralikrishna, K. An overview on NMR spectroscopy based metabolomics. Int. J. Pharm. Sci. Dev. Res. 2020, 6, 016-020. [CrossRef]

176. Ried, J.S.; Baurecht, H.; Stuckler, F.; Krumsiek, J.; Gieger, C.; Heinrich, J.; Kabesch, M.; Prehn, C.; Peters, A.; Rodriguez, E.; et al. Integrative genetic and metabolite profiling analysis suggests altered phosphatidylcholine metabolism in asthma. Allergy 2013, 68, 629-636. [CrossRef]

177. Jung, J.; Kim, S.H.; Lee, H.S.; Choi, G.S.; Jung, Y.S.; Ryu, D.H.; Park, H.S.; Hwang, G.S. Serum metabolomics reveals pathways and biomarkers associated with asthma pathogenesis. Clin. Exp. Allergy 2013, 43, 425-433. [CrossRef]

178. Chang, C.; Guo, Z.G.; He, B.; Yao, W.Z. Metabolic alterations in the sera of Chinese patients with mild persistent asthma: A GC-MS-based metabolomics analysis. Acta Pharmacol. Sin. 2015, 36, 1356-1366. [CrossRef]

179. Reinke, S.N.; Gallart-Ayala, H.; Gomez, C.; Checa, A.; Fauland, A.; Naz, S.; Kamleh, M.A.; Djukanovic, R.; Hinks, T.S.; Wheelock, C.E. Metabolomics analysis identifies different metabotypes of asthma severity. Eur. Respir. J. 2017, 49. [CrossRef] [PubMed]

180. Pang, Z.; Wang, G.; Wang, C.; Zhang, W.; Liu, J.; Wang, F. Serum Metabolomics Analysis of Asthma in Different Inflammatory Phenotypes: A Cross-Sectional Study in Northeast China. BioMed Res. Int. 2018, 2018, 2860521. [CrossRef] [PubMed]

181. Bochenek, G.; Nizankowska, E.; Gielicz, A.; Swierczynska, M.; Szczeklik, A. Plasma 9alpha,11beta-PGF2, a PGD2 metabolite, as a sensitive marker of mast cell activation by allergen in bronchial asthma. Thorax 2004, 59, 459-464. [CrossRef] [PubMed]

182. Comhair, S.A.; McDunn, J.; Bennett, C.; Fettig, J.; Erzurum, S.C.; Kalhan, S.C. Metabolomic Endotype of Asthma. J. Immunol. 2015, 195, 643-650. [CrossRef] [PubMed]

183. Jiang, T.; Dai, L.; Li, P.; Zhao, J.; Wang, X.; An, L.; Liu, M.; Wu, S.; Wang, Y.; Peng, Y.; et al. Lipid metabolism and identification of biomarkers in asthma by lipidomic analysis. Biochim. Biophys. Acta Mol. Cell Biol. Lipids 2021, 1866, 158853. [CrossRef] [PubMed]

184. Liu, Y.; Zheng, J.; Zhang, H.P.; Zhang, X.; Wang, L.; Wood, L.; Wang, G. Obesity-Associated Metabolic Signatures Correlate to Clinical and Inflammatory Profiles of Asthma: A Pilot Study. Allergy Asthma Immunol. Res. 2018, 10, 628-647. [CrossRef]

185. Loureiro, C.C.; Duarte, I.F.; Gomes, J.; Carrola, J.; Barros, A.S.; Gil, A.M.; Bousquet, J.; Bom, A.T.; Rocha, S.M. Urinary metabolomic changes as a predictive biomarker of asthma exacerbation. J. Allergy Clin. Immunol. 2014, 133, 261-263.e5. [CrossRef]

186. Loureiro, C.C.; Oliveira, A.S.; Santos, M.; Rudnitskaya, A.; Todo-Bom, A.; Bousquet, J.; Rocha, S.M. Urinary metabolomic profiling of asthmatics can be related to clinical characteristics. Allergy 2016, 71, 1362-1365. [CrossRef] 
187. Kolmert, J.; Gomez, C.; Balgoma, D.; Sjodin, M.; Bood, J.; Konradsen, J.R.; Ericsson, M.; Thorngren, J.O.; James, A.; Mikus, M.; et al. Urinary Leukotriene E4 and Prostaglandin D2 Metabolites Increase in Adult and Childhood Severe Asthma Characterized by Type 2 Inflammation. A Clinical Observational Study. Am. J. Respir. Crit. Care Med. 2021, 203, 37-53. [CrossRef]

188. Wheelock, C.E.; Goss, V.M.; Balgoma, D.; Nicholas, B.; Brandsma, J.; Skipp, P.J.; Snowden, S.; Burg, D.; D’Amico, A.; Horvath, I.; et al. Application of 'omics technologies to biomarker discovery in inflammatory lung diseases. Eur. Respir. J. 2013, 42, 802-825. [CrossRef]

189. Ibrahim, B.; Marsden, P.; Smith, J.A.; Custovic, A.; Nilsson, M.; Fowler, S.J. Breath metabolomic profiling by nuclear magnetic resonance spectroscopy in asthma. Allergy 2013, 68, 1050-1056. [CrossRef]

190. Ntontsi, P.; Ntzoumanika, V.; Loukides, S.; Benaki, D.; Gkikas, E.; Mikros, E.; Bakakos, P. EBC metabolomics for asthma severity. J. Breath Res. 2020, 14, 036007. [CrossRef]

191. Motta, A.; Paris, D.; D'Amato, M.; Melck, D.; Calabrese, C.; Vitale, C.; Stanziola, A.A.; Corso, G.; Sofia, M.; Maniscalco, M. NMR metabolomic analysis of exhaled breath condensate of asthmatic patients at two different temperatures. J. Proteome Res. 2014, 13, 6107-6120. [CrossRef]

192. Sinha, A.; Desiraju, K.; Aggarwal, K.; Kutum, R.; Roy, S.; Lodha, R.; Kabra, S.K.; Ghosh, B.; Sethi, T.; Agrawal, A. Exhaled breath condensate metabolome clusters for endotype discovery in asthma. J. Transl. Med. 2017, 15, 262. [CrossRef]

193. Maniscalco, M.; Paris, D.; Melck, D.J.; D’Amato, M.; Zedda, A.; Sofia, M.; Stellato, C.; Motta, A. Coexistence of obesity and asthma determines a distinct respiratory metabolic phenotype. J. Allergy Clin. Immunol. 2017, 139, 1536-1547.e5. [CrossRef]

194. Snowden, S.; Dahlen, S.E.; Wheelock, C.E. Application of metabolomics approaches to the study of respiratory diseases. Bioanalysis 2012, 4, 2265-2290. [CrossRef]

195. Horgan, R.P.; Kenny, L.C. Omic technologies: Genomics, transcriptomics, proteomics and metabolomics. Obestetrician Gynaecol. 2011, 13, 189-195. [CrossRef]

196. Hodge, S.E. Linkage analysis versus association analysis: Distinguishing between two models that explain disease-marker associations. Am. J. Hum. Genet. 1993, 53, 367-384.

197. Donovan, B.M.; Bastarache, L.; Turi, K.N.; Zutter, M.M.; Hartert, T.V. The current state of omics technologies in the clinical management of asthma and allergic diseases. Ann. Allergy Asthma Immunol. 2019, 123, 550-557. [CrossRef]

198. Hegde, P.S.; White, I.R.; Debouck, C. Interplay of transcriptomics and proteomics. Curr. Opin. Biotechnol. $2003,14,647-651$. [CrossRef]

199. Ivanova, O.; Richards, L.B.; Vijverberg, S.J.; Neerincx, A.H.; Sinha, A.; Sterk, P.J.; Maitland-van der Zee, A.H. What did we learn from multiple omics studies in asthma? Allergy 2019, 74, 2129-2145. [CrossRef]

200. Abdel-Aziz, M.I.; Neerincx, A.H.; Vijverberg, S.J.; Kraneveld, A.D.; Maitland-van der Zee, A.H. Omics for the future in asthma. Semin. Immunopathol. 2020, 42, 111-126. [CrossRef]

201. Teran, L.M.; Montes-Vizuet, R.; Li, X.; Franz, T. Respiratory proteomics: From descriptive studies to personalized medicine. J. Proteome Res. 2015, 14, 38-50. [CrossRef]

202. Neerincx, A.H.; Vijverberg, S.J.H.; Bos, L.D.J.; Brinkman, P.; van der Schee, M.P.; de Vries, R.; Sterk, P.J.; Maitland-van der Zee, A.H. Breathomics from exhaled volatile organic compounds in pediatric asthma. Pediatr. Pulmonol. 2017, 52, 1616-1627. [CrossRef]

203. Wu, G. Functional amino acids in growth, reproduction, and health. Adv. Nutr. 2010, 1, 31-37. [CrossRef]

204. Wu, G. Amino acids: Metabolism, functions, and nutrition. Amino Acids 2009, 37, 1-17. [CrossRef]

205. Ricciardolo, F.L.; Sterk, P.J.; Gaston, B.; Folkerts, G. Nitric oxide in health and disease of the respiratory system. Physiol. Rev. 2004, 84, 731-765. [CrossRef]

206. Folkerts, G.; Kloek, J.; Muijsers, R.B.; Nijkamp, F.P. Reactive nitrogen and oxygen species in airway inflammation. Eur. J. Pharmacol. 2001, 429, 251-262. [CrossRef]

207. Xu, W.; Comhair, S.A.A.; Janocha, A.J.; Lara, A.; Mavrakis, L.A.; Bennett, C.D.; Kalhan, S.C.; Erzurum, S.C. Arginine metabolic endotypes related to asthma severity. PLoS ONE 2017, 12, e0183066. [CrossRef]

208. Xu, W.; Ghosh, S.; Comhair, S.A.; Asosingh, K.; Janocha, A.J.; Mavrakis, D.A.; Bennett, C.D.; Gruca, L.L.; Graham, B.B.; Queisser, K.A.; et al. Increased mitochondrial arginine metabolism supports bioenergetics in asthma. J. Clin. Investig. 2016, 126, $2465-2481$. [CrossRef]

209. Asosingh, K.; Lauruschkat, C.D.; Alemagno, M.; Frimel, M.; Wanner, N.; Weiss, K.; Kessler, S.; Meyers, D.A.; Bennett, C.; Xu, W.; et al. Arginine metabolic control of airway inflammation. JCI Insight 2020, 5. [CrossRef]

210. Zehethofer, N.; Bermbach, S.; Hagner, S.; Garn, H.; Muller, J.; Goldmann, T.; Lindner, B.; Schwudke, D.; Konig, P. Lipid Analysis of Airway Epithelial Cells for Studying Respiratory Diseases. Chromatographia 2015, 78, 403-413. [CrossRef]

211. Wendell, S.G.; Baffi, C.; Holguin, F. Fatty acids, inflammation, and asthma. J. Allergy Clin. Immunol. 2014, 133, 1255-1264. [CrossRef] [PubMed]

212. Miyata, J.; Arita, M. Role of omega-3 fatty acids and their metabolites in asthma and allergic diseases. Allergol. Int. 2015, 64, 27-34. [CrossRef] [PubMed]

213. Park, H.; Choi, Y.; Jung, C.G.; Park, H.S. Potential Biomarkers for NSAID-Exacerbated Respiratory Disease. Mediat. Inflamm. 2017, 2017, 8160148. [CrossRef] [PubMed] 
214. Ammit, A.J.; Hastie, A.T.; Edsall, L.C.; Hoffman, R.K.; Amrani, Y.; Krymskaya, V.P.; Kane, S.A.; Peters, S.P.; Penn, R.B.; Spiegel, S.; et al. Sphingosine 1-phosphate modulates human airway smooth muscle cell functions that promote inflammation and airway remodeling in asthma. FASEB J. 2001, 15, 1212-1214. [CrossRef] [PubMed]

215. Kim, S.H.; Jung, H.W.; Kim, M.; Moon, J.Y.; Ban, G.Y.; Kim, S.J.; Yoo, H.J.; Park, H.S. Ceramide/sphingosine-1-phosphate imbalance is associated with distinct inflammatory phenotypes of uncontrolled asthma. Allergy 2020, 75, 1991-2004. [CrossRef] [PubMed]

216. Bahlas, S.; Damiati, L.A.; Al-Hazmi, A.S.; Pushparaj, P.N. Decoding the Role of Sphingosine-1-Phosphate in Asthma and Other Respiratory System Diseases Using Next Generation Knowledge Discovery Platforms Coupled With Luminex Multiple Analyte Profiling Technology. Front. Cell Dev. Biol. 2020, 8, 444. [CrossRef]

217. Trinh, H.K.; Kim, S.C.; Cho, K.; Kim, S.J.; Ban, G.Y.; Yoo, H.J.; Cho, J.Y.; Park, H.S.; Kim, S.H. Exploration of the Sphingolipid Metabolite, Sphingosine-1-phosphate and Sphingosine, as Novel Biomarkers for Aspirin-exacerbated Respiratory Disease. Sci. Rep. 2016, 6, 36599. [CrossRef]

218. Global Initiative for Asthma. Global Strategy for Asthma Management and Prevention. 2021. Available online: www.ginasthma. org (accessed on 15 May 2021).

219. Pite, H.; Morais-Almeida, M.; Rocha, S.M. Metabolomics in asthma: Where do we stand? Curr. Opin. Pulm. Med. 2018, 24, 94-103. [CrossRef]

220. Panda, L.; Gheware, A.; Rehman, R.; Yadav, M.K.; Jayaraj, B.S.; Madhunapantula, S.V.; Mahesh, P.A.; Ghosh, B.; Agrawal, A.; Mabalirajan, U. Linoleic acid metabolite leads to steroid resistant asthma features partially through NF-kappaB. Sci. Rep. 2017, 7, 9565. [CrossRef]

221. Mabalirajan, U.; Rehman, R.; Ahmad, T.; Kumar, S.; Singh, S.; Leishangthem, G.D.; Aich, J.; Kumar, M.; Khanna, K.; Singh, V.P.; et al. Linoleic acid metabolite drives severe asthma by causing airway epithelial injury. Sci. Rep. 2013, 3, 1349. [CrossRef]

222. Lessard, A.; Turcotte, H.; Cormier, Y.; Boulet, L.P. Obesity and asthma: A specific phenotype? Chest 2008, 134, 317-323. [CrossRef]

223. Peters, U.; Dixon, A.E.; Forno, E. Obesity and asthma. J. Allergy Clin. Immunol. 2018, 141, 1169-1179. [CrossRef]

224. Leiria, L.O.; Martins, M.A.; Saad, M.J. Obesity and asthma: Beyond T(H)2 inflammation. Metabolism 2015, 64, 172-181. [CrossRef]

225. Periyalil, H.A.; Gibson, P.G.; Wood, L.G. Immunometabolism in obese asthmatics: Are we there yet? Nutrients 2013, 5, 3506-3530. [CrossRef]

226. Rastogi, D.; Fraser, S.; Oh, J.; Huber, A.M.; Schulman, Y.; Bhagtani, R.H.; Khan, Z.S.; Tesfa, L.; Hall, C.B.; Macian, F. Inflammation, metabolic dysregulation, and pulmonary function among obese urban adolescents with asthma. Am. J. Respir. Crit. Care Med. 2015, 191, 149-160. [CrossRef]

227. Xie, B.; Waters, M.J.; Schirra, H.J. Investigating potential mechanisms of obesity by metabolomics. J. BioMed Biotechnol. 2012, 2012, 805683. [CrossRef]

228. Choi, S.; Snider, A.J. Sphingolipids in High Fat Diet and Obesity-Related Diseases. Mediat. Inflamm 2015, 2015, 520618. [CrossRef]

229. Sturgill, J.L.; Khosravi, M.; Allegood, J.; 2, S.S. Ceramide as a Key Player in Obesity Exacerbated Asthma. Am. J. Respir. Crit. Care Med. 2019, 199. [CrossRef]

230. Choi, Y.; Kim, M.; Kim, S.J.; Yoo, H.J.; Kim, S.H.; Park, H.S. Metabolic shift favoring C18:0 ceramide accumulation in obese asthma. Allergy 2020, 75, 2858-2866. [CrossRef]

231. Gowda, G.A.; Zhang, S.; Gu, H.; Asiago, V.; Shanaiah, N.; Raftery, D. Metabolomics-based methods for early disease diagnostics. Expert Rev. Mol. Diagn. 2008, 8, 617-633. [CrossRef]

232. Checkley, W.; Deza, M.P.; Klawitter, J.; Romero, K.M.; Klawitter, J.; Pollard, S.L.; Wise, R.A.; Christians, U.; Hansel, N.N. Identifying biomarkers for asthma diagnosis using targeted metabolomics approaches. Respir. Med. 2016, 121, 59-66. [CrossRef] 